\title{
A socio-spatial analysis of urban transformation at a neighborhood scale: The case of the relocation of Kadifekale inhabitants to TOKI Uzundere in İzmir
}

\author{
Meltem Eranıl Demirli ${ }^{\mathrm{a}, 1}$, Zeynep Tuna Ultav ${ }^{\mathrm{b}, *}$, Neslihan Demirtaş-Milz ${ }^{\mathrm{c}}$ \\ ${ }^{a}$ Bilkent University, Art, Design and Architecture Program, Graduate School of Economics and Social Sciences, Turkey \\ ${ }^{\mathrm{b}}$ Yaşar University, Faculty of Architecture, Department of Interior Architecture and Environmental Design, Üniversite Cad. 35-37, 35100 Bornova, Izmir, Turkey \\ ${ }^{c}$ Izmir University of Economics, Faculty of Arts and Sciences, Department of Sociology, Sakarya Cad. No. 156, 35330 Balcova, Izmir, Turkey
}

\section{A R T I C L E I N F O}

\section{Article history:}

Received 31 December 2014

Received in revised form 28 June 2015

Accepted 28 June 2015

Available online 17 July 2015

\section{Keywords:}

Urban transformation

Relocation

Neighborhood

Kadifekale

TOKI Uzundere

Social space

\section{A B S T R A C T}

Particularly in the last two decades, urban governors have presented urban transformation projects as ideal solutions to help low-income urban residents improve their living conditions. However, the way they have been carried out and their consequences mean that these projects do not, in most cases, bring the expected improvements. Most projects involve relocating residents to new, more peripheral districts of the city, which causes social isolation and certain socio-spatial incompatibilities between their previous and new habitats.

Using a case from Izmir in Turkey, this study aims to analyze such socio-spatial incompatibilities in the lives of low-income residents that are caused by relocation within the framework of urban transformation projects. One of Izmir's earliest inner-city gecekondu neighborhoods, Kadifekale was chosen by Izmir Metropolitan Municipality as a site for urban transformation due to the risk of landslide in the area. Before the start of the project, the neighborhood contained 7324 housing units accommodating rural-to-urban migrants, mainly from the southeast of Turkey. This urban transformation project aimed to relocate at least some of the inhabitants from their homes in Kadifekale to recently constructed apartment blocks in the TOKI Uzundere Public Housing Project on the periphery of the city. Although many residents were reluctant to exchange their houses for new apartments, some were persuaded to move to TOKI, which was presented as the ideal solution by the municipal officials.

This study critically evaluates the Kadifekale urban transformation project, particularly with regard to the relocation of some Kadifekale residents from their one- or two-story houses in Kadifekale to apartment blocks on the periphery of the city. The analysis is based on a comparison between the socio-spatial experiences of migrants in Kadifekale and their recent experiences in Uzundere and the possibility of certain incompatibilities in these two experiences. The argument aims to demonstrate the changed conditions of social life and daily life practices as a result of altered spatial properties at a neighborhood scale: their use of outdoor spaces, the meanings they attributed to neighborhood space ("intimacy of place" within categories of sensual (visual and olfactory) recognition), and their sociospatial network. The argument draws both implicitly and explicitly on Henri Lefebvre's spatial triad and De Certeau's conceptualization of tactic versus strategy as the major conceptual inspirations for this study.

(c) 2015 Elsevier Ltd. All rights reserved.

\footnotetext{
* Corresponding author.

E-mail addresses: meltem.eranil@bilkent.edu.tr (M. Eranıl Demirli), zeynep.tunaultav@yasar.edu.tr (Z. Tuna Ultav),neslihan.demirtas@ieu.edu.tr (N. Demirtaş-Milz).

$1 \mathrm{PhD}$ candidate.
} 


\section{Introduction}

The aim of this study is to critically analyze the socio-spatial consequences of relocating the residents of Izmir's oldest inner-city gecekondu ${ }^{2}$ neighborhood that accommodates rural-to-urban migrants from the southeast of Turkey who have arrived in Izmir in large numbers primarily since the 1990s as a consequence of forced migration. Under the "Konak Urban Transformation Project" (Figs. 1 and 2), the migrants were supposed to be relocated from Kadifekale neighborhood, which is located at the center of the city, to Uzundere, a peripheral district composed of apartment blocks built by TOKi ${ }^{3}$ (EIA Report, 2005). With the agreement of TOKI, Izmir Metropolitan Municipality and Konak Municipality (a district municipality), Kadifekale was incorporated into the framework of the 'Konak Urban Transformation Project' in 2005. The plan projected the demolition of 1968 houses in Kadifekale and the relocation of their residents to newly-built high-rise apartments in Uzundere (Fig. 3) due to an "imminent" risk of landslide in certain parts of the neighborhood as acknowledged by the state by law. ${ }^{4}$ However, according to narratives gathered from immigrant residents, the way this relocation has been conducted has caused severe problems in their daily lives, their socio-economic status in the city and their social networks. While other studies conducted on the Kadifekale urban transformation project have dealt with various consequences of and problems in the conduct of the project (see Demirtaş-Milz, 2013; Saraçoğlu \& Demirtaş-Milz, 2014), the main objective of this article is to critically analyze the incompatibilities between the residents' past socio-spatial habits in Kadifekale and the spatial features of the new district in TOKI Uzundere.

The practices of urban transformation in Turkey have generated much debate. As reported by Balamir (2006) and Altınörs Çırak and Yörür (2006), the last two decades (2000s and 2010s) have involved a problem-solving approach to the urban context that is mostly dependent on transformation rather than a concern for upgrading the conditions of immigrant residents and their settlement without relocation. According to Ulusoy (2006, p. 4), Turkey's urban political elites have frequently described the function of these projects as "wiping out operations" for an "urban

\footnotetext{
2 “Gecekondu literally means 'built overnight'. It refers to houses or settlements constructed on state and/or privately-owned land without planning and/or construction permission, through the efforts of rural-to-urban migrants and their home region fellows in urban peripheries. Owing to populist policies, amnesty laws that aim to formalize the status of these settlements, or informal state practices at various levels to supply services to these settlements over the past four decades, it is no longer possible to define these settlements using the formal context of urban politics and the classical concept of gecekondu".

3 TOKI (Toplu Konut İdaresi Başkanlı̆̆l) stands for the "Housing Development Administration of Turkey", which was founded as a governmental entity in 1984. In the EIA report of the Housing Development Administration of Turkey (2005), the aim of TOKI is stated as providing the necessary communal support and organizing services in order to supply the housing needs of the country, and provide orderly urbanization. However, it should be noted that standardized TOKI housing units have also provoked a critical architectural debate in Turkey in recent decades.

4 The risk of a landslide in the area cannot be underestimated. However, certain factors, such as the human-induced/policy-related causes of landslide, the delay of nearly 30 years before the municipality started the project, the possible underlying neoliberal concerns of urban regeneration behind the project, and the lack of a socially responsible agenda in the conduct of the project are considered by some scholars as factors that bring into question the sincerity of claims by the project holders regarding the risk of landslide (see Saraçoğlu \& Demirtaş-Milz, 2014): "The discourses of 'urgency' and that of 'natural disasters' served to conceal the structural problems and to depict the project as an unquestionable technical intervention to address the imminent dangers posed by a landslide" (see Saraçoğlu \& Demirtaş-Milz, 2014).
}

tumor" (Ünsal \& Kuyucu, 2010). ${ }^{5}$ In his critique of the neoliberal urban policies of the last two decades in Turkey, Tekeli (2014) argues that the government presents urban transformation as a grand scheme; a far-reaching political project of top priority for the country.

The literature on urban transformation projects in the largest cities of Turkey indicate the following main problems in the way they are conducted: land and real estate speculation caused by the projects; relocation of low-income settlers from their neighborhoods either to other low-income settlements or to newly built apartment blocks on urban peripheries; and the physical and infra-structural problems of these newly built apartment blocks (see Demirtaş-Milz, 2013; Kuyucu and Ünsal, 2010; Saraçoğlu \& Demirtaş-Milz, 2014). This study mainly deals with the last two problems mentioned above by taking into account the fact that the social consequences of the new spatial contexts offered to the users have as much to tell as the spatial interventions themselves. It should also be noted that low-income residents within the framework of these projects often end up isolated from city spaces and forced to live on the outskirts of the city. This is the case for those former Kadifekale residents who were resettled in TOKI Uzundere neighborhood, who had been used to living close to the center of Izmir (Figs. 4 and 5). ${ }^{6}$ Considering that many of these immigrant residents have informal jobs like street selling or harvesting and selling mussels, being close to the city center is crucial for reducing their living costs. ${ }^{7}$

TOKI Uzundere is neither a unique case in İzmir nor in Turkey. By 2015, the construction sector became the fastest growing sector in Turkey with a ratio of $24.6 \%$. TOKI, in general, is seen as "a catalyst for the construction industry" (Building Turkey of the Future, 2011). Fig. 6 shows the operation areas and the total number of housing units produced by TOKI over the last 30 years. TOKI Uzundere project lies in the category of "conversion of shanty houses (urban renewal projects)", within which 47 of 248 ongoing

\footnotetext{
${ }^{5}$ In the history of urban transformation in Turkey, the 1980s was a period of significant changes (Aydınlı \& Turan, 2012). Ataöv sees the wide use of "urban restructuring" policies as the most important feature of urban transformation projects during this period. The 2000s are described as the period where "transformation" was for the first time strategically defined through the dense collaboration of the private sector and local authorities (Ataöv \& Osmay, 2007). It is also important to note that, in 2004, "Urban Transformation" processes were legitimized by law (Issue 5162) in Turkey. Unlike recent western examples, where "urban vitalization, rehabilitation, improvement and conservation" have come to the forefront, local authorities in Turkey prefer to concentrate more on the strategy of "urban transformation" (Ataöv \& Osmay, 2007).

6 The distance from Kadifekale to the city center is $0.5 \mathrm{~km}$. On the other hand, the distance from TOKI Uzundere to the city center is $15.5 \mathrm{~km}$.

7 This constitutes of one the most important factors in most migrants' rejection of the municipality's offer of a place in the TOKI Uzundere housing project. Many migrants either took their cases to court to get greater compensation for their houses in Kadifekale or immediately accepted the value of their gecekondu houses as defined by the municipality in order to find a house to buy or rent in nearby gecekondu districts. In this sense, the project does not seem to have been very successful in transforming the area and improving the living conditions of the migrant residents, but will instead lead to relocation within Kadifekale for many migrants and the emergence of informal land speculation within these districts due to the resulting scarcity of gecekondu housing. There are many reasons behind this. The first is related to financial matters. There is a big difference between the value offered by the municipality to the owners of gecekondu houses (in compensation for demolition) and the cost of the offered TOKI flats. Consequently, residents accepting the municipality's offer were supposed to also pay 350-600 YTL monthly installments for 15-20 years to the state, depending on the values determined for their gecekondu houses. The second reason behind the low rate of acceptance on the part of the migrant residents is that many house owners only have informal proof of their property ownership, while the majority of residents are tenants who are totally excluded from the formal context of the project. The third reason is the socio-spatial incompatibilities between the migrants' life styles/socio-economic conditions and the location and spatial features of TOKI Uzundere. This last reason will be discussed in depth in this article.
} 

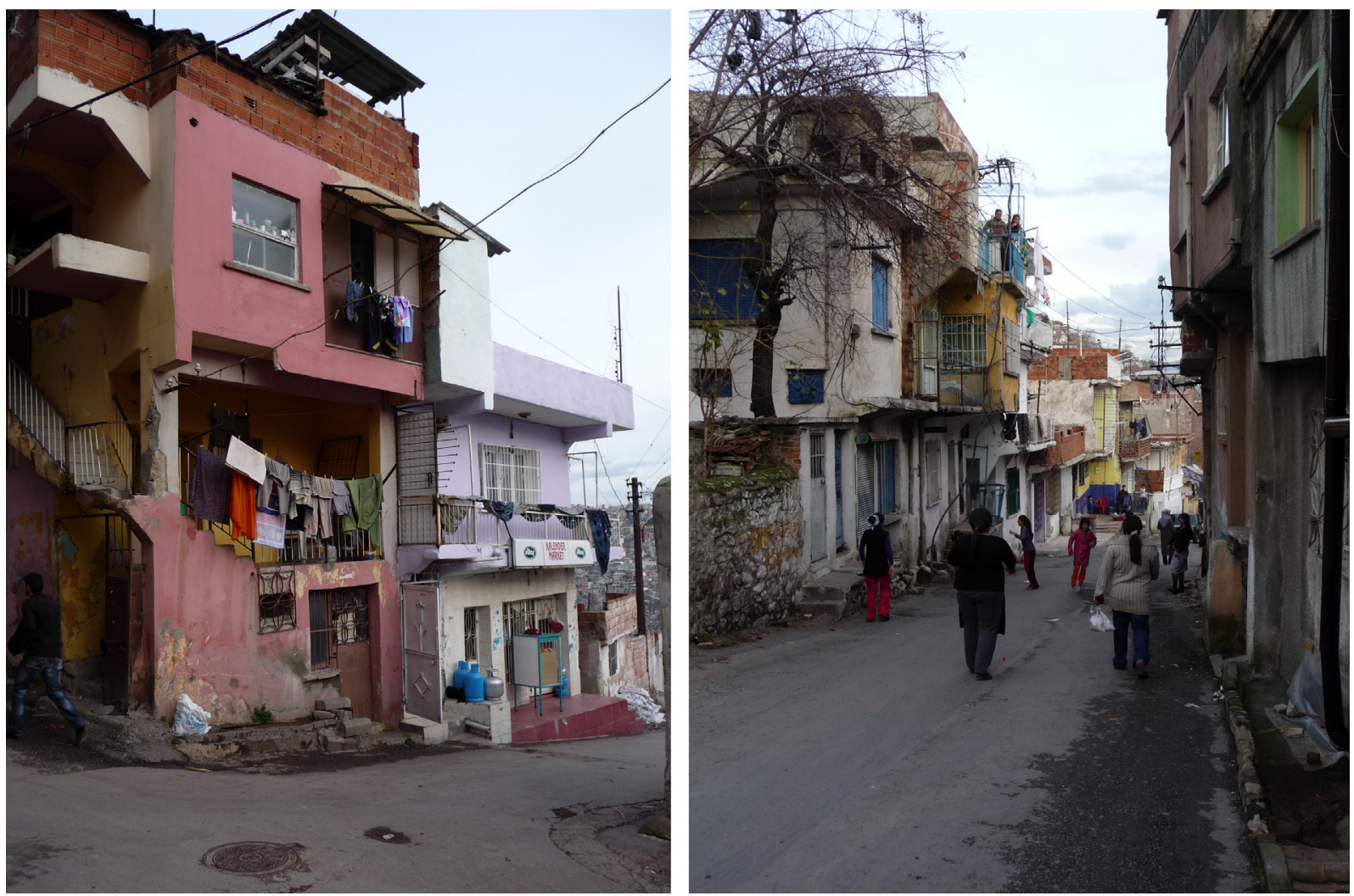

Fig. 1. Scenes from Kadifekale neighborhood, 2010 (Author 1 archive).
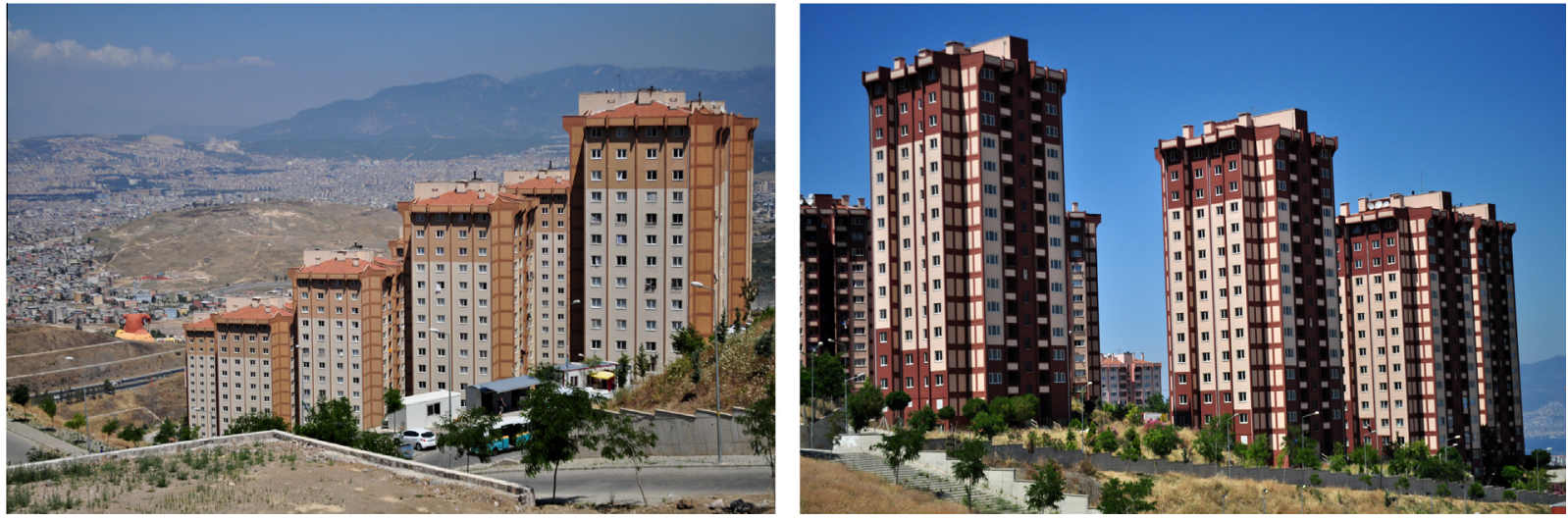

Fig. 2. TOKI Uzundere settlement, 2013 and 2014 (Author 1 and 2 archives).

urban transformation projects have already been completed and that will produce approximately 185,000 housing units in total through two major operating actors: one of these is TOKI itself as an "over-authorized actor" (Tekeli, 2014, p. xxiii); the other is the relevant municipality for each project ${ }^{8}$ (Fig. 7).

Given this background, this study analyzes the urban transformation of Kadifekale at a neighborhood scale, ${ }^{9}$ including both spatial and social analysis, in order to understand the intertwined nature of these two realms and the incompatibilities that they can

\footnotetext{
${ }^{8}$ Starting from 2005, municipalities with a population above 50,000 gained authority to proclaim urban transformation sites and to implement the transformation as per article 73 within Municipal Law 5393. However, TOKI is still viewed as the leading actor in the literature. See Türkün, Öktem Ünsal, \& Yapıcı, 2014.

${ }^{9}$ While this study considers changes at a neighborhood scale, it is also possible to analyze the changes in housing at an urban scale.
}

generate in two different socio-spatial contexts: Kadifekale and Uzundere.

The main method of the study involves site analysis using visual data collection in both Kadifekale and TOKI Uzundere. It also uses official documents, such as drawing sets and TOKI reports. To understand the way people carry out their daily practices in the spatial structures of Kadifekale, and their habits and social relations, in-depth, semi-structured interviews were conducted with 10 inhabitants before their relocation. These interviews were supported by informal conversations and informal group interviews with many migrants living in both Kadifekale and, more recently, in Uzundere. The interviews and conversations mainly focused on understanding the socio-spatial practices of migrants in Kadifekale and the socio-spatial opportunities Uzundere provides them. That is, the interviews and informal talks attempted to 


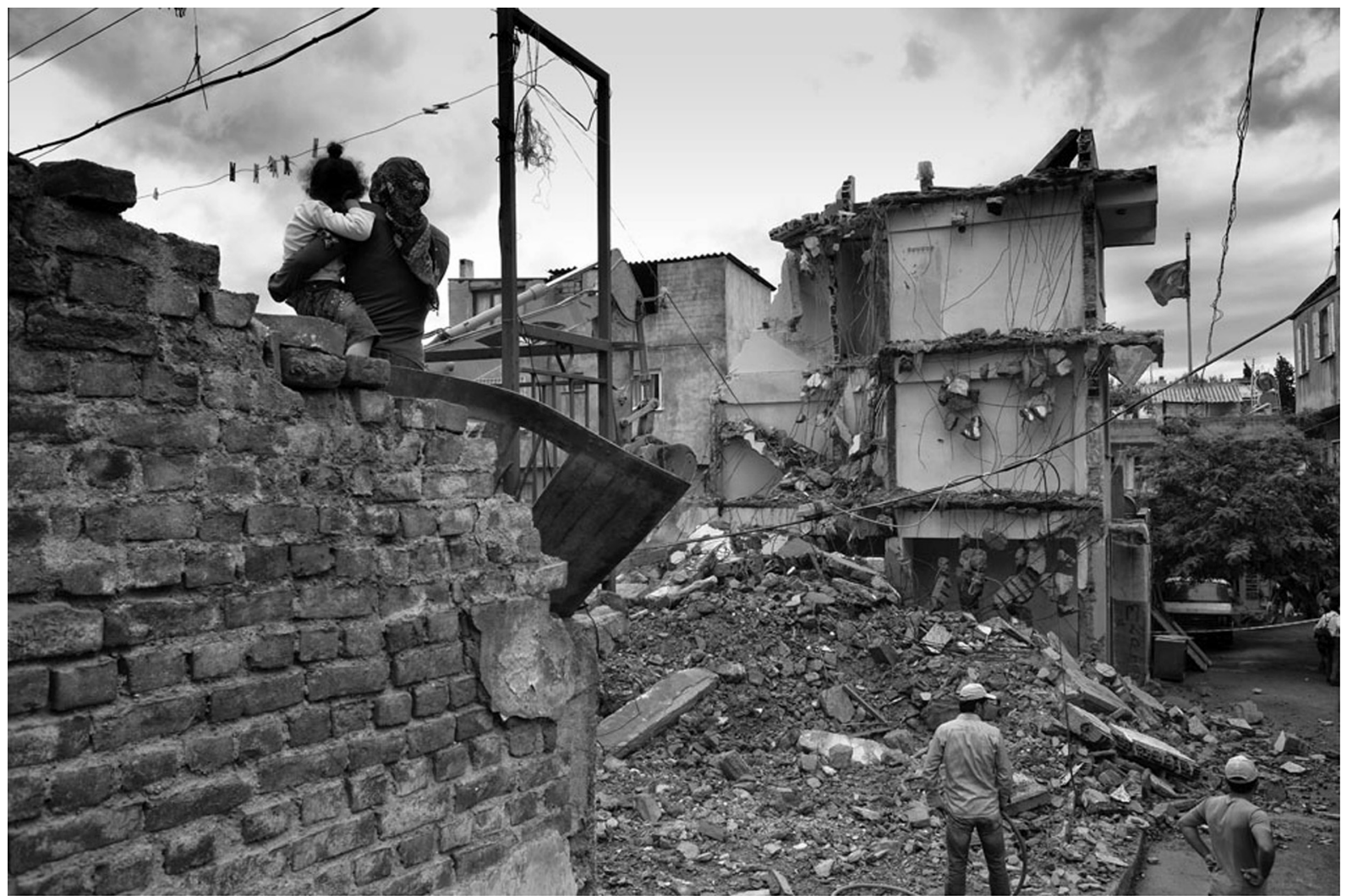

Fig. 3. View of demolished Kadifekale houses (Donuktan archive) <http://www.kodacollective.com/photographers>.

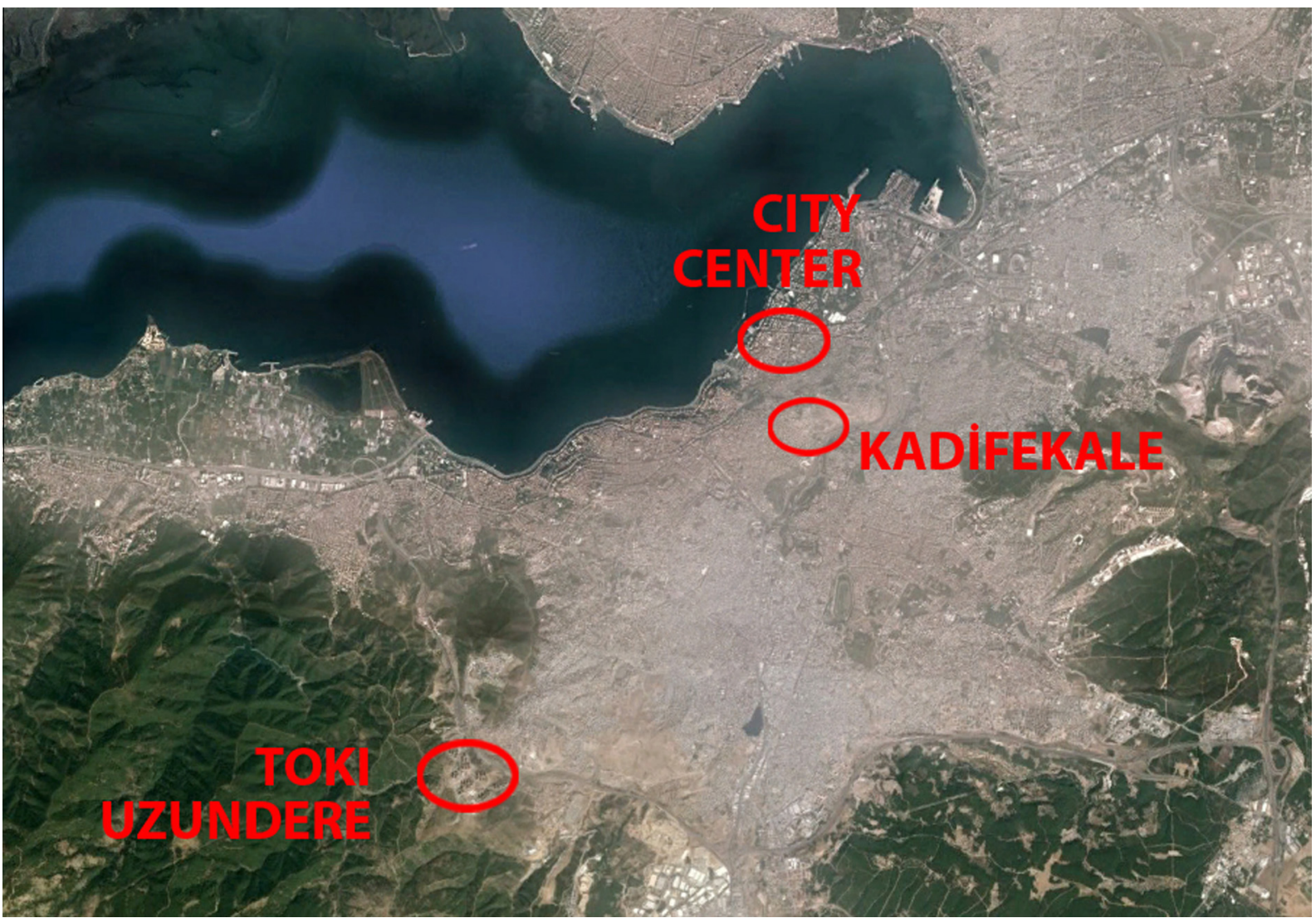

Fig. 4. Satellite image showing the locations of Izmir city center, Kadifekale and TOKI Uzundere (Google Earth image edited by the authors). 

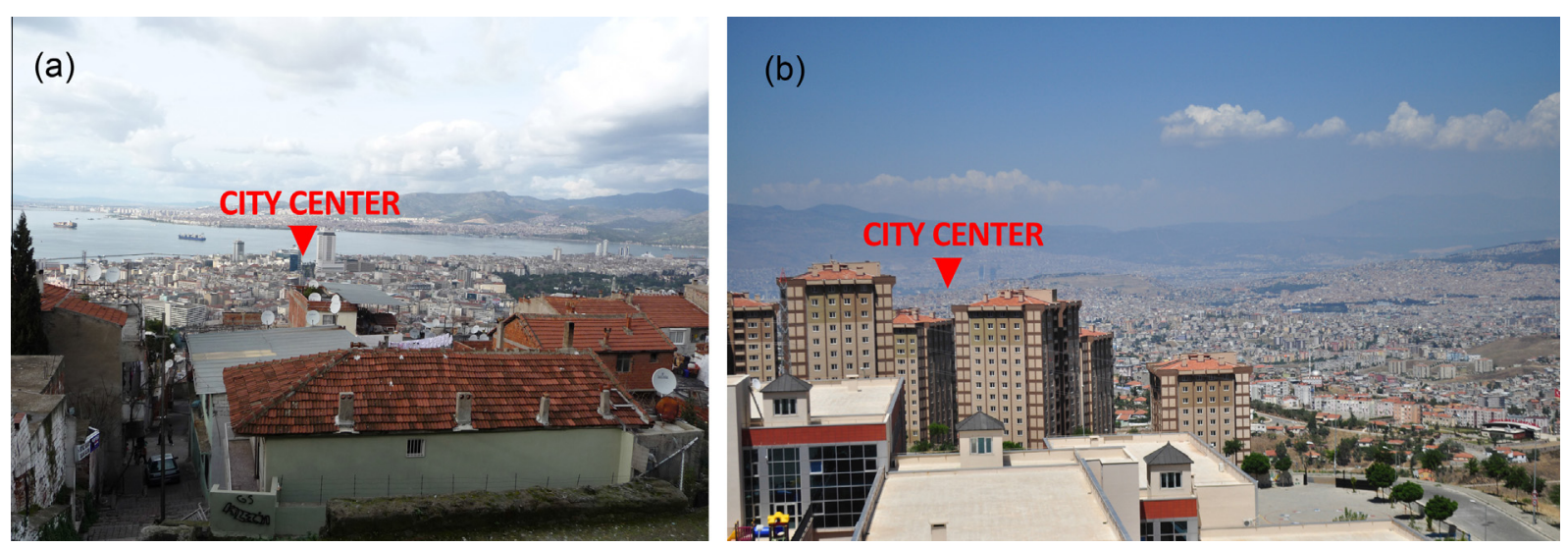

Fig. 5. Views illustrating the distances to the city center: (a) From Kadifekale; (b) from TOKi Uzundere (Author 1 archive).

elaborate the immigrant residents' daily practices in the open/public spaces of both settings. Particularly in Kadifekale, the study sought extended responses from the residents to questions about how long they have been living in the neighborhood, how they use its streets, open spaces and semi-public spaces in front of their houses, how they communicate with their neighbors, and how they make use of their gardens. Other specific questions aimed to uncover any differences in responses between men, women and children regarding their socio-spatial practices. Following their relocation, the new TOKI Uzundere residents were asked about their new daily spatial routines during several observational trips to the site.

Conceptually, the study was inspired by Lefebvre's idea of the "production of space", which "opposes social and political theory conceiving space as a static 'container' or 'platform' which carries social relations" (Brenner, 1997). In his criticisms of modernist planning, Lefebvre engages with this understanding of space via his spatial triad. In this triad, space is defined as an outcome of the dialectical interplay between three moments/realms of social spatialization: (i) spatial practice (perceived space) as in the material or built environment produced by society; (ii) representations of space (conceived space), which is the space of planners, urbanists, technocratic subdividers and social engineers; (iii) representational space (lived space), i.e. the space directly lived through its associated images and symbols, hence the space of inhabitants and users (Lefebvre, 1998, pp. 37-39, 50). Though in his book: 'The Production of Space', Lefebvre emphasizes the power and the determining capacity of the absolute space of capitalism, he also sees a strong possibility for spontaneity in all holistic and modernist urban planning (Demirtaş, 2009, p. 35). That is, while Lefebvre acknowledges that the absolute space of capitalism has an overriding determining capacity over the everyday spatial practices of ordinary users, he nevertheless insists that there is always a possibility of spatial resistance or spontaneity regarding the realm of lived space and the practices of 'weaker' parties in the system. Thus, through Rob Shield's (1991, p. 164) reading of Lefebvre's triad, one can identify within the framework of lived space "clandestine and underground spatial practices, which suggest and prompt alternative restructurings of institutionalized discourses of space and new modes of spatial praxis, such as squatters, illegal aliens, and thirds world slum dwellers, who fashion a spatial presence and practice outside the norms of prevailing (enforced) social spatialization" (cited in Demirtaş, 2009, p. 35). Parallel to Shield's reading of Lefebvre, Michel De Certeau (1984, p. 29), in his analysis of everyday life, foresees a differentiation between strategy and tactic. In his definition, the informal spatial practices mentioned above should be considered within the realm of tactics, because the strategic realm belongs to the power holders. Strategy is designed with a proper locus and planning, based on creating places in conformity with abstract models. In contrast, tactics belong to the "other" and lacks the option of planning a general strategy; rather, a tactic "operates in isolated actions, makes use of the opportunity and chance offerings of the moment" (De Certeau, 1984, p. 37). Ordinary people's tactics reveal creative spatial practices: alternative uses, re-appropriations and alterations of the strategic space (the space of holistic and modernist projects), which is mostly uninformed about the socio-spatial needs of the 'other'. That is, the 'conceived' spaces of urban developers and the terms of their projects do not coincide, in most cases, with the life-worlds and needs of the users or inhabitants of these spaces. This potential irreconcilability, as foreseen by Lefebvre, between the realms of the triad and the spontaneity of social agency, and between strategy and tactic by De Certeau, can be used as quite important conceptual inspirations for examining recent urban transformation projects and their socio-spatial consequences. This question of how relocation affects the way the relocated Kadifekale inhabitants experience their daily life practices constitutes the main concern of this article; specifically, it seems important to understand the incompatibilities between residents' spatial needs and the spatial opportunities provided in the new TOKI Uzundere housing project.

\section{Relocation from Kadifekale to TOKI Uzundere}

Particularly within the framework of the current government's neoliberal policies over the last decade, urban transformation projects have been presented as reshaping and upgrading Turkey's urban image by creating the "modern" living standards seen in the new neighborhoods for the relocated users of urban space. From examining a very similar case of relocation in Egypt, Fahra Ghannam (2002) argues that the modern apartment represents the objectification of the state's understanding of modernity. She brilliantly portrays the way that relocated residents of the al-Zawiya al-Hamra public housing units in Cairo reshaped their "modern" apartment blocks according to their daily needs and habits derived from their past socio-spatial practices. Through its enforced relocation project during 1979-1981, the Egyptian state articulated its modernist discourse in the production of urban space with new public housing units being included in the urban texture as modern apartments. In this sense, while the relocated residents are struggling to appropriate modern facilities, for example by raising domestic animals on their apartment block 


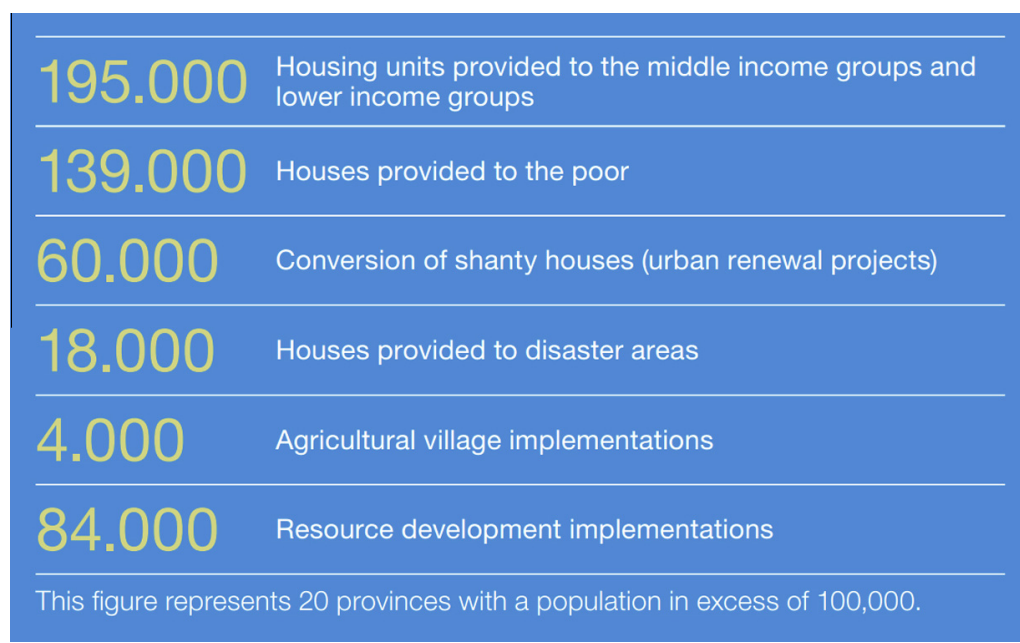

Fig. 6. Operation areas and total number of housing units produced within TOKI (http://www.toki.gov.tr/AppResources/UserFiles/files/TOKI-11_ENG.pdf).

balconies, this can be read as demonstrating their efforts to continue their previous customs. Similarly, the neglected use of the apartment front doors, which prevents the loss of their established community network, is an example of a tactic to resist modernist strategies.

Meanwhile, the relocated local urban poor, who were forced to migrate from Bulaq, are portrayed in public discourse as more active contributors to the country's economic progress after relocation. That is, the Egyptian state promotes life in modern settings as a way to integrate the urban poor, who are otherwise marginal and passive urban citizens, into modern city life by upgrading their living spaces (Ghannam, 2002). As Ghannam notes, the space where the relocated inhabitants used to live was regarded as "backward, isolated, and uncivilized, in that sense its existence in the heart of the capital of the Middle East and Africa" was portrayed highly inappropriate (Ghannam, 2002, p. 33).

Bourdieu (1979) suggests that we should consider the public representations of the inhabitants of existing "undeveloped" spaces as "unhealthy, marginal and/or isolated others" as a tool to justify urban transformation projects and relocation within the realm of symbolic violence. The media also help to consolidate this negative image, as in the case of the urban transformation projects in Turkey, by generally perceiving and representing the gecekondu phenomenon from a modernist perspective; considering them as "an irrational and illegal form of urbanization" that "threatens modernist ideals and values". That is, they present gecekondus as a cause of degeneration, arguing for their elimination from cities (Akbulut \& Başlık, 2011, p. 40).

In particular, since the late 1990s, in parallel with the emergence of neoliberal policies and socio-structural transformations taking place within gecekondu settlements themselves, the public image of gecekondu houses has become even more negative. As discussed by Demirtas and Sen (2007, p. 92), the gecekondu concept started to be used in conjunction with news stories dealing with illegal construction and ownership, and struggles between police forces and gecekondu residents over house demolitions. Another concept, 'varoş', emerged to symbolize a discursive change regarding gecekondu settlements, referring to extreme politicization, violence, criminal activities and informality (Demirtas \& Sen, 2007, p. 92). Kadifekale is a typical example, in that it has almost exclusively hosted poor Kurdish migrants, mostly as tenants, and has been subject to an othering process, particularly since the early 1990 s.

According to government agencies, the urban transformation project in Kadifekale will make the district more secure, both structurally in response to the landslide danger in Kadifekale, but also socially regarding the area's "problematic" political image as a space of Kurdish extremism within Izmir's wider beautification project. Consequently, Kadifekale will be redeveloped as a new city-center attraction, possibly for example through Izmir Metropolitan Municipality including Kadifekale into city life and using it as a touristic resource. ${ }^{10}$ Thus, although the officially-declared reason for Kadifekale's transformation was to protect its population from landslide threats, the authorities, business circles and local media outlets have celebrated the demolition of its buildings for another reason: to enhance Izmir's image. "According to this way of thinking, transforming a seemingly 'blighted slum' into a modern recreational zone would have a positive impact on the way the whole of Izmir is seen from outside" (Saraçoğlu \& Demirtaş-Milz, 2014, p. 188).

Unfortunately, although presented in public discourse as a "modern" and "urban" alteration to gecekondu life, the TOKI Uzundere project has a socio-spatial design that does not seem to consider or reflect any of the socio-spatial habits and needs of the newcomers from Kadifekale. Yet, according to official presentations, it has all the social benefits that Kadifekale lacks so that future generations will grow up in a physically and socially "healthy" environment. Clearly, therefore, the issue of whether TOKI Uzundere effectively meets the needs and demands of Kadifekale inhabitants needs to be investigated.

\section{Production of meaning through Kadifekale's spatial aspects}

As Berman notes, "[1]ife between buildings comprises the entire spectrum of activities, which combine to make communal spaces in cities and residential areas meaningful and attractive". He then argues that it is important to use outdoor spaces "to experience other people functioning in various situations" (Berman, 2007, p. 28) and "to communicate, which is the prerequisite for socialization and the development of self and does not only mean the flow and exchange of information, goods and people" (Barlas, 2006, p. 72). Face-to-face interactions can best take place in a streetscape, making the street the most important urban component in human relations (Barlas, 2006, p. 75). This importance is increased even further in Turkey's gecekondus, given the traditional and communal lifestyle there (Fig. 8). This study will focus on how, as a traditional neighborhood, Kadifekale reflects the socio-spatial qualities of communal living, particularly the role of "spatial practice" at a

\footnotetext{
10 See (Baran \& Çiçek, 2006) for state policies
} 


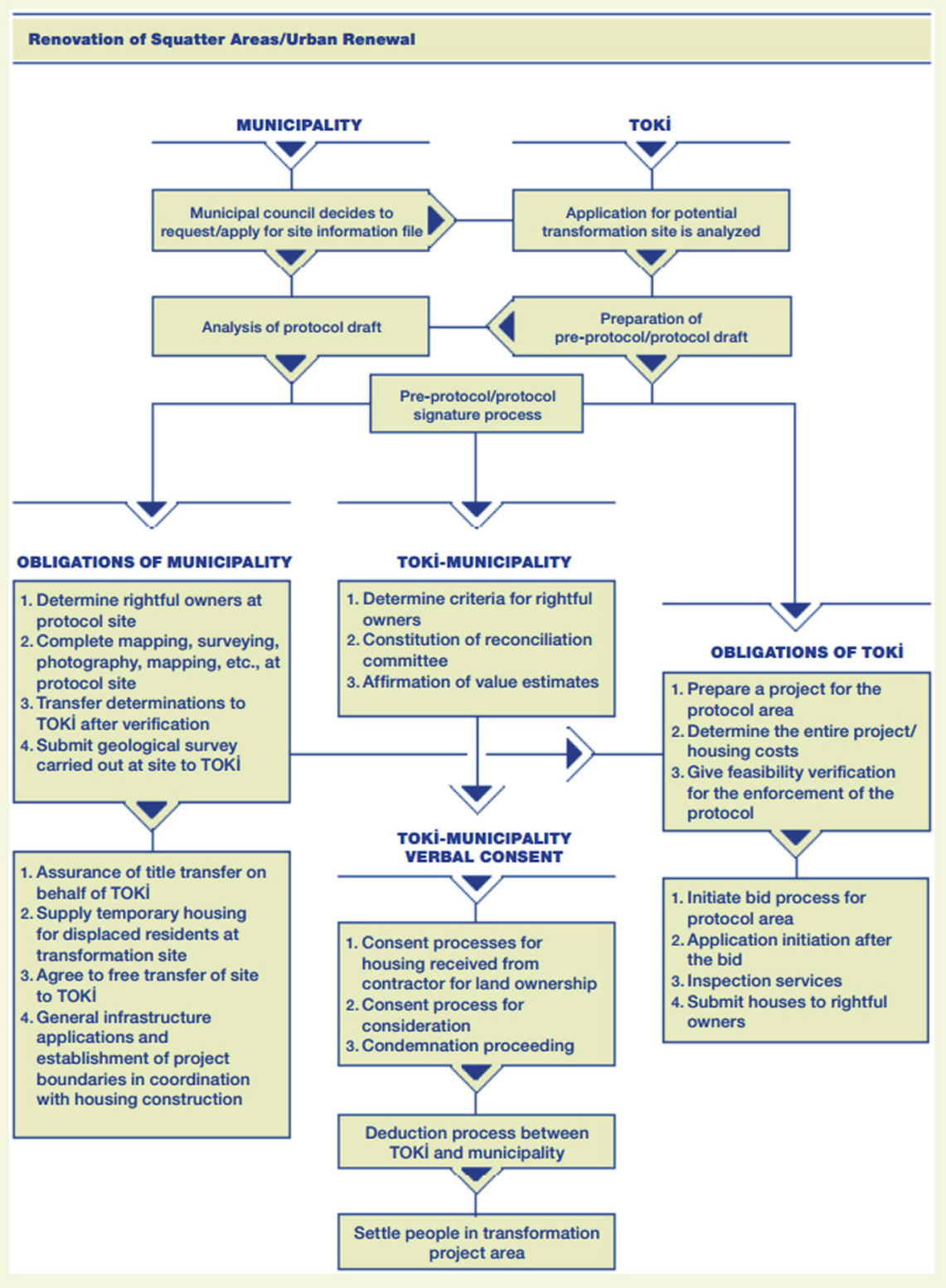

Fig. 7. The roles of authorities in the operation area of Urban Transformation (http://www.toki.gov.tr/AppResources/UserFiles/files/TOKI-11_ENG.pdf).

neighborhood scale through the use of public or semi-public spaces, such as streets, common open grounds, public buildings and gardens. Many of the respondents in this study stressed the intense interactions between inhabitants on the streets or in spaces between houses, which can be considered as semi-public/private spaces in gecekondu settings like Kadifekale. In İzmir, with its Mediterranean climate of warm winters, the year-round use of these outdoor spaces is apparent to an observer.

The interview questions aimed to reveal the residents' daily spatial life routines regarding the intense use of outdoor spaces. Both the interviews and observations showed the extent to which residents like to gather in large numbers on the streets for special occasions like wedding ceremonies (Fig. 9) or funerals; or sometimes just to be together for no specific reasons, when they may set up tables and sit outside with neighbors. Other open spaces, such as balconies or gardens, may be used for keeping domestic animals (Fig. 10), storing household items or for smoking outside the house. These semi-private outside spaces thus provide some comfort and freedom to individual gecekondu dwellers in the highly dense, restricted and observant life spaces of the gecekondu. For example, one 19-year-old male respondent who has lived with his family in Kadifekale for 15 years following their migration from Mardin, said that, since he is obliged to use the living room of the house as his bedroom, he uses the balcony as his private space for leisure time with his computer, smoking without his parents' noticing or even sleeping there on hot summer nights. In another example, a woman explained that, since their house is on the ground floor, she has turned her balcony into a small shop from where she can sell groceries. She also stated that they reserve a space in their garden at the beginning of each fall to keep dry food. Two other women respondents, who are 36 and 26 years old, similarly stated that they use their gardens for storing things and for winter preparations, such as making pepper or tomato sauce. Most respondents store coal, dry their laundry or cook barbecues in their gardens. One female respondent compared Kadifekale and TOKI regarding the use of balconies: 


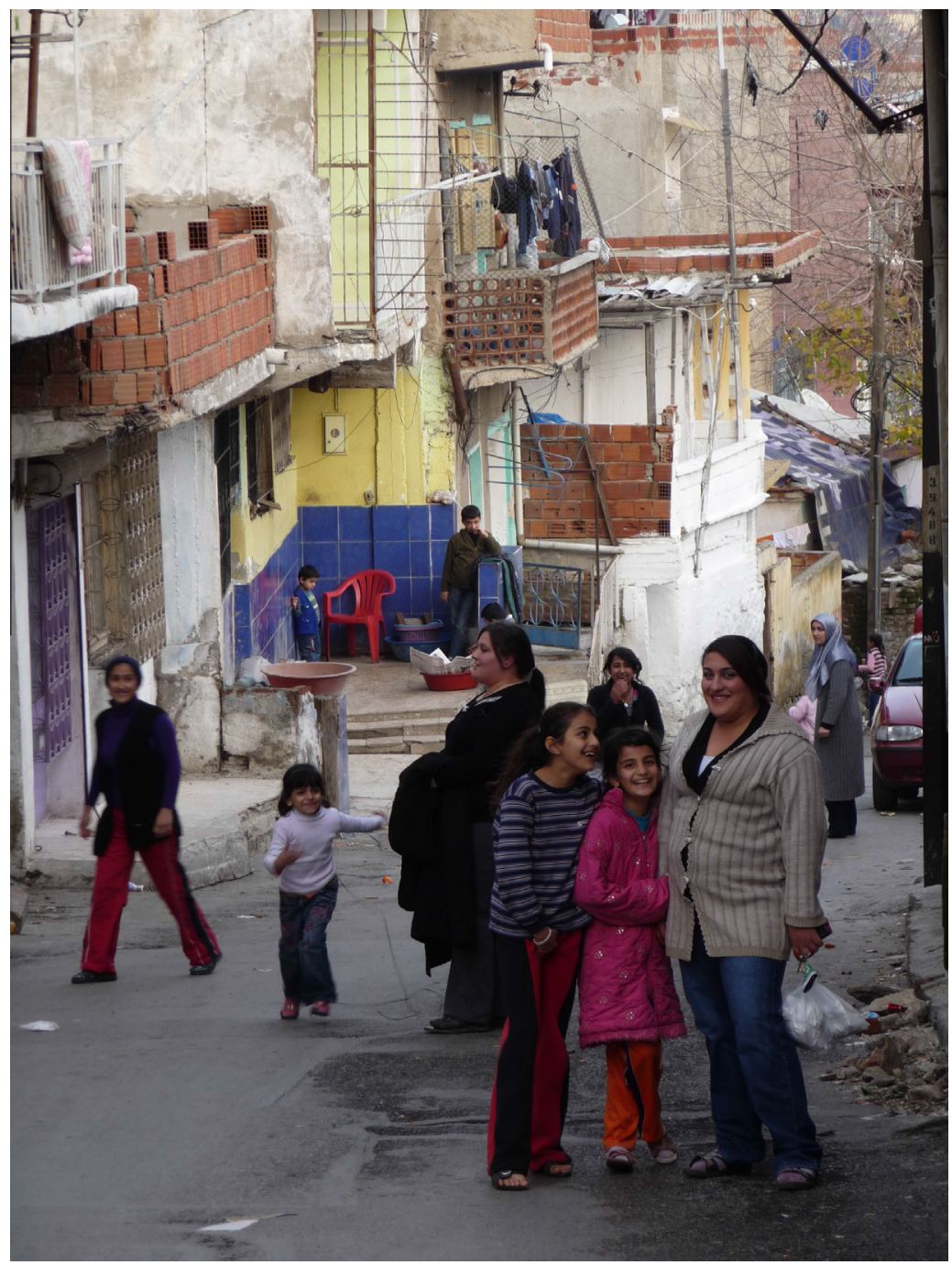

Fig. 8. Liveliness of Kadifekale streets, 2010 (Author 1 archive).

Generally, we welcome our guests in our living room. In nice weather, I get them to the balcony. We like our balcony so much and use it quite a lot. The balconies in TOKI are two square meters, that's all.

The value given to the outdoor spaces related to their houses is also explicit in the same respondent's statements about the use of their garden:

Our tenant is using our garden. They use the garden for the purpose of laundry-drying, as a flower garden and a storage place at the same time. Life is easy and fine here in that sense; we dry our laundry or make our tomato sauce outside. There is nothing good over there [referring to the balconies in TOKI Uzundere], not even a spacious balcony.

Our respondents also stated that they held their wedding ceremonies in outdoor public spaces in the neighborhood. In spring, fall and summer, football fields in the neighborhood are used for wedding ceremonies. Only in winter are weddings performed in the neighorhood's coffee house.

TOKI Uzundere public housing, on the other hand, does not allow this flexibility, having been planned and constructed in a way that undermines, to a large extent, the users' previous socio-spatial habits and practices. This incompatibility between the new space and social life has emerged from a lack of consideration on the part of planners and project implementers. Perhaps this was inevitable, as Lefebvre (1998, p. 37) argues through his distinction between conceived and lived spaces: "Even neo capitalism or organize capitalism, even technocratic planners and programmers, cannot produce a space with a perfectly clear understanding of cause and effect, motive and implication". ${ }^{11}$

From observation of the two locations, it becomes clear that while the narrow streets of Kadifekale are used for collective activities, the open spaces in the new public housing project were originally planned to be reserved as green areas. In the EIA Report for TOKI, $40 \%$ of the project site was reserved as green area with the landscape designed accordingly (EIA Report, 2005). However, such green areas have been unable to accommodate the traditional public activities of former Kadifekale inhabitants, such as wedding ceremonies or raising animals; rather, they seem to have remained sterile, unused, empty areas, with landscaping that has still not been properly completed. That is, the organic urban fabric observed in Kadifekale is lacking in TOKI Uzundere. Another factor is the increase in urban scale compared to Kadifekale. This new scale, created by the high-rise apartment buildings, subjugates both the individual and open public spaces for collective occasions, although there are still some un-designed common areas (Fig. 11).

\footnotetext{
11 Italics in original.
} 


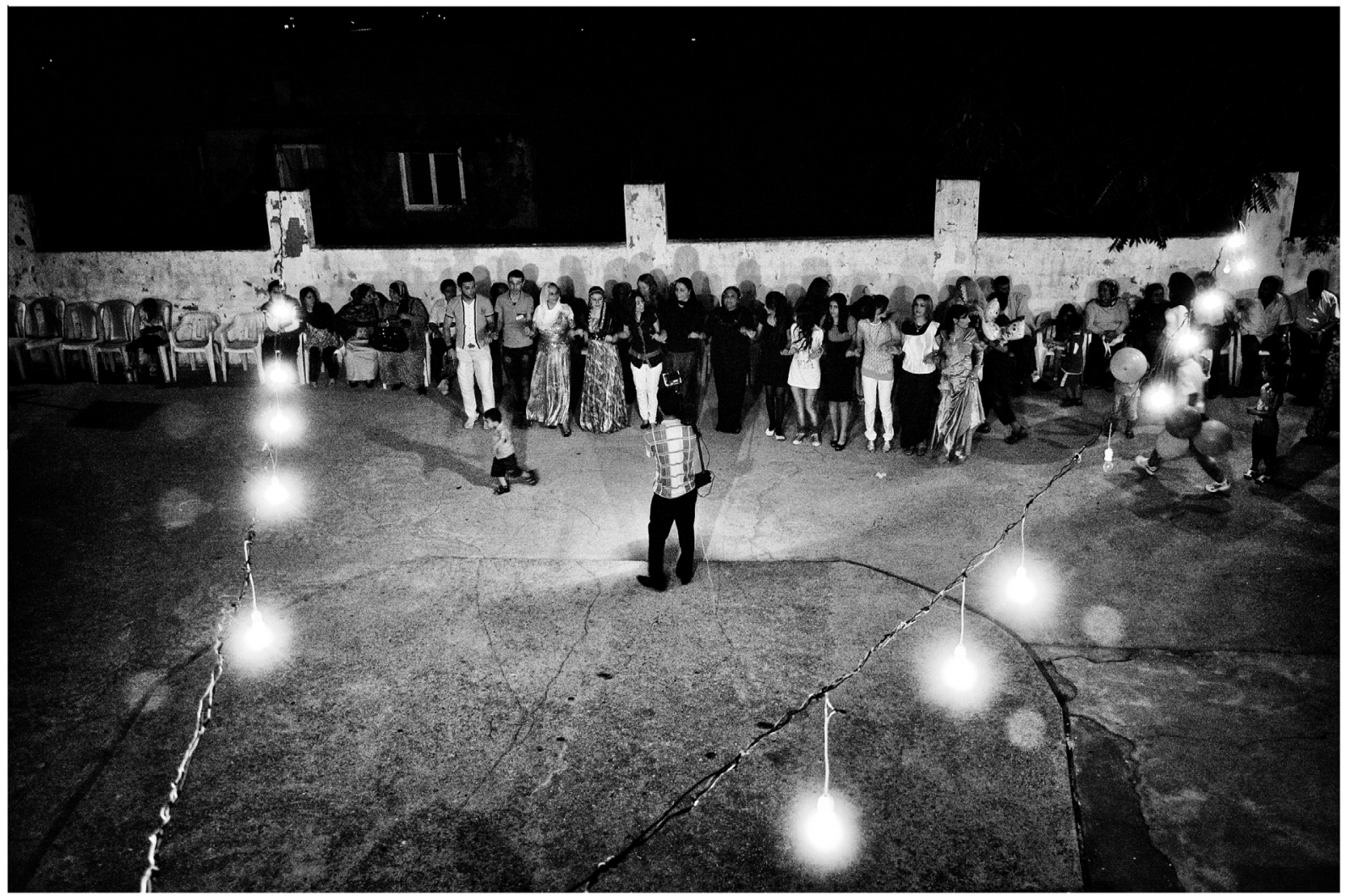

Fig. 9. Wedding ceremony in Kadifekale (Serkan Çolak/MahzenPhotos archive).
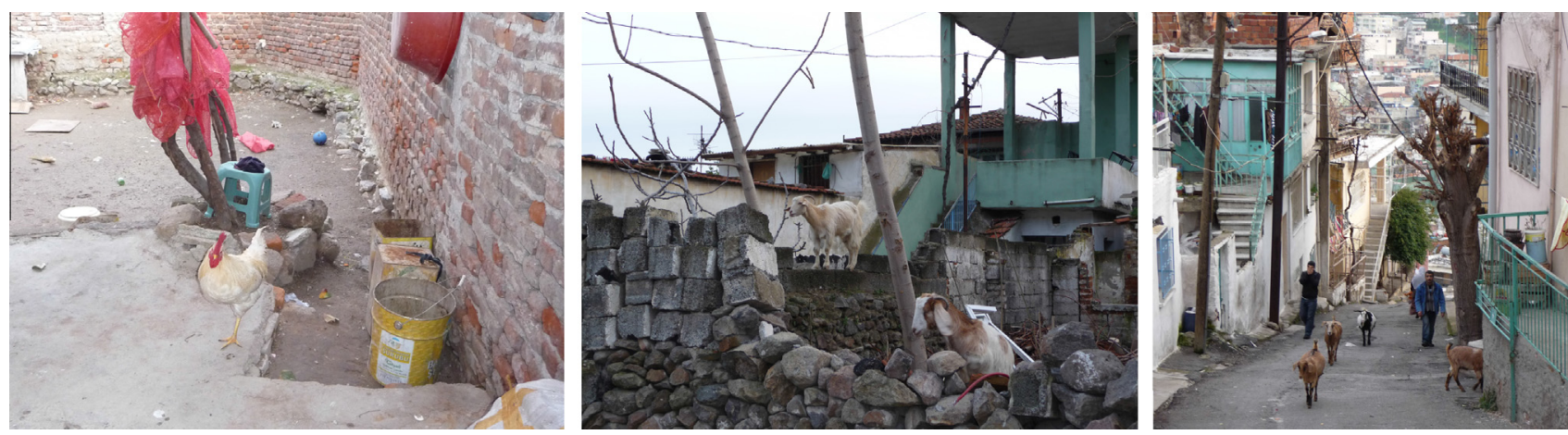

Fig. 10. Domestic animals in Kadifekale, 2010 (Author 1 archive)

As TOKI Uzundere's new inhabitants try to maintain their customs and daily life practices, they bring seating from their apartments to the supposedly green areas. Despite the lack of spaces for traditional public activities like wedding ceremonies, the inhabitants tactically transform and change the space according to their needs. One 58 year-old respondent in TOKI Uzundere reported how they now perform their wedding celebrations in between the apartment blocks:

Organization is not a problem. Each family brings a table and chair for the wedding ceremony. But noise is the main problem. It is disturbing other residents. There is a wedding-hall close to the neighborhood [referring to TOKI Uzundere], but we cannot afford it.

In this new setting, loud noise outside constitutes a serious problem for some residents. This change of attitude can be explained by the fact that, in Kadifekale, places for celebrating such occasions (e.g. the tea garden located within the walls of Kadifekale castle) were located at some distance from residential areas, and since every neighbor used to be invited to the celebrations anyway, noise was not considered a problem.

The vertical design of the new apartments also restricts opportunities for sociability. Ghannam referred to the same problem regarding the al-Zawiya al-Hamra housing area (Ghannam, 2002, p. 171). "Just as the individual apartment did not respect the fluidity of daily practices, the changing size of the family, or the interaction between neighbors, the project at large did not address the need for diversification, flexible social interactions, or mixing of activities". ${ }^{12}$ What Ghannam refers to is that horizontal settlement better supports a social network system than a vertical one since social interaction is greater in the former case because of easier visual connections. When planners disregard the third dimension

\footnotetext{
12 Since the study of Ghannam (2002) focuses on urban transformation in Cairo, it also provides a relevant example for the case in this study.
} 

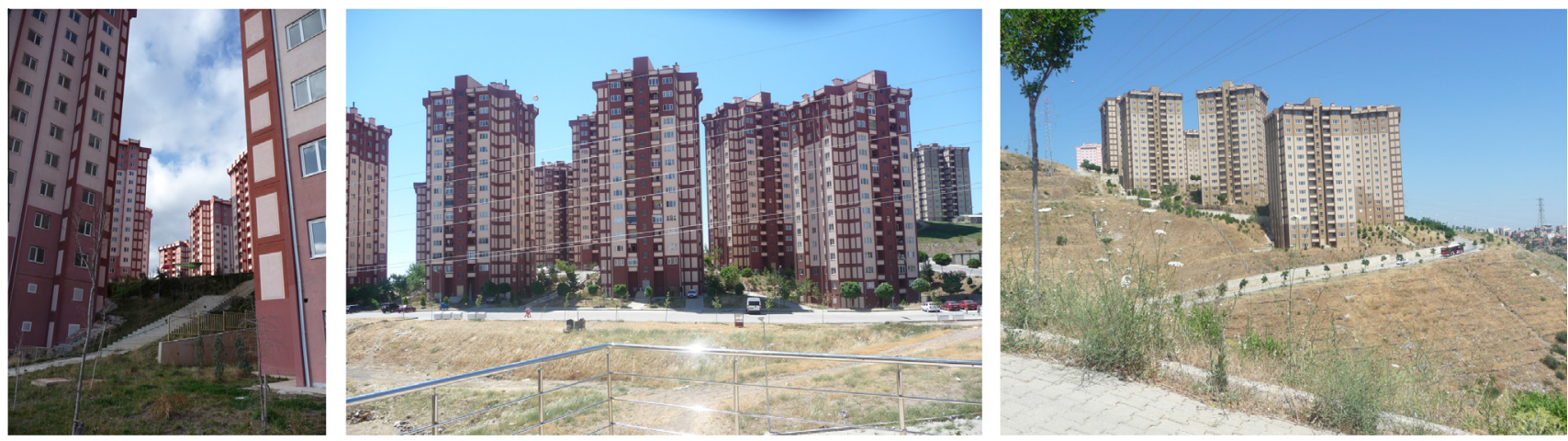

Fig. 11. Un-landscaped, unfinished open public spaces in TOKI Uzundere, 2010 and 2013 (Author 1 and 2 archives).
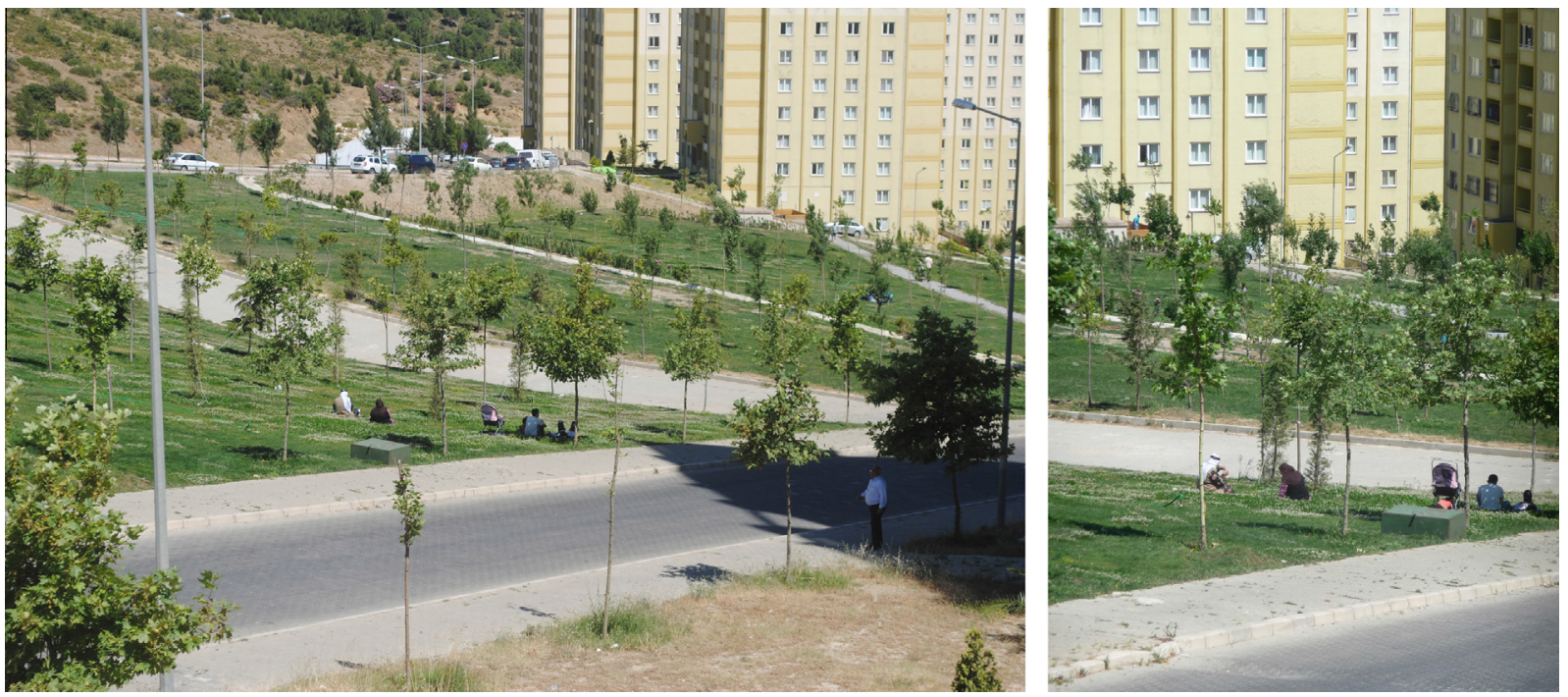

Fig. 12. TOKI Uzundere users meeting or resting in the green areas of the neighborhood, 2013 (Author 1 archive).

by only considering two-dimensional land use plans, they ignore the relationships between buildings, spaces and human behavior.

The vertical planning of the housing units in TOKI Uzundere means that it will no longer be possible to sit outside the front door and chat with other neighbors since the new housing units are designed to create boundaries against the outer world, which will have consequences for social life. In TOKI Uzundere, inhabitants can no longer experience street life and socialize as they did before because of the vertical axes of the apartment blocks. Although it was observed that they sometimes meet in the green spaces (Fig. 12), the vertical design is, to a large extent, incompatible with the inhabitants' previous outdoor habits in Kadifekale. For example, in Uzundere, you rarely see children playing or teenagers socializing on the streets (Fig. 13), old people sitting quietly in front of their front doors for fresh air or watching the daily routines of others. There are no longer scenes of women going shopping at small neighborhood shops, cleaning the streets that merge with the spaces of their own houses, gathering in front of the houses to chat or help each other, for example in producing stuffed mussels (Figs. 14 and 15). As our thirty-five-year-old female respondent told us, at evening times in Kadifekale, whenever she felt bored, she would just put a rug in front of her house door and sit down to chat with her neighbors. The men cannot spend their time playing card games in the local coffee house in Uzundere as was the case in Kadifekale. In addition to the loss of public space, verticality has 'privatized' the home space in that the introduction of apartment living has made individual housing units more closed-off. In contrast, in Kadifekale, with its primarily horizontal structure, the housing units and gardens were more approachable by neighbors and others.

It is particularly important for children to be able to play outside with other children in safety and monitored by adults. As Gehl (1987) demonstrates, whether the neighborhood comprises single-family houses or apartment housing, children tend to play more on the streets near the entrances of dwellings and parking areas rather than in the playgrounds, which are often unsupervisable because they are more distant from the children's families or other adults. In this study, too, both the interview responses and personal observations indicate that Kadifekale's children were mostly used to playing on the streets, in their gardens or in other enclosed outdoor spaces (Fig. 16). Although some play areas have been created in TOKI Uzundere, because of the stagnant street life, children seemed reluctant to play in places isolated from their community (Fig. 17). Due to the sport field, children play on empty green spaces, car-parking areas or the liminal spaces between the apartment blocks in TOKI Uzundere (Fig. 18). Meanwhile, the designed play areas are underused, being likely to turn into "lost spaces". ${ }^{13}$ A similar pattern of use of the common areas is observed for women and elderly people (Fig. 19), with an old man taking his chair to sit in the middle of a car park while a group of women sit on the pavement to chat while doing lacework. As these observations show, the residents are trying to continue their old rituals in

\footnotetext{
13 The concept was suggested by Trancik. See Trancik (1986).
} 


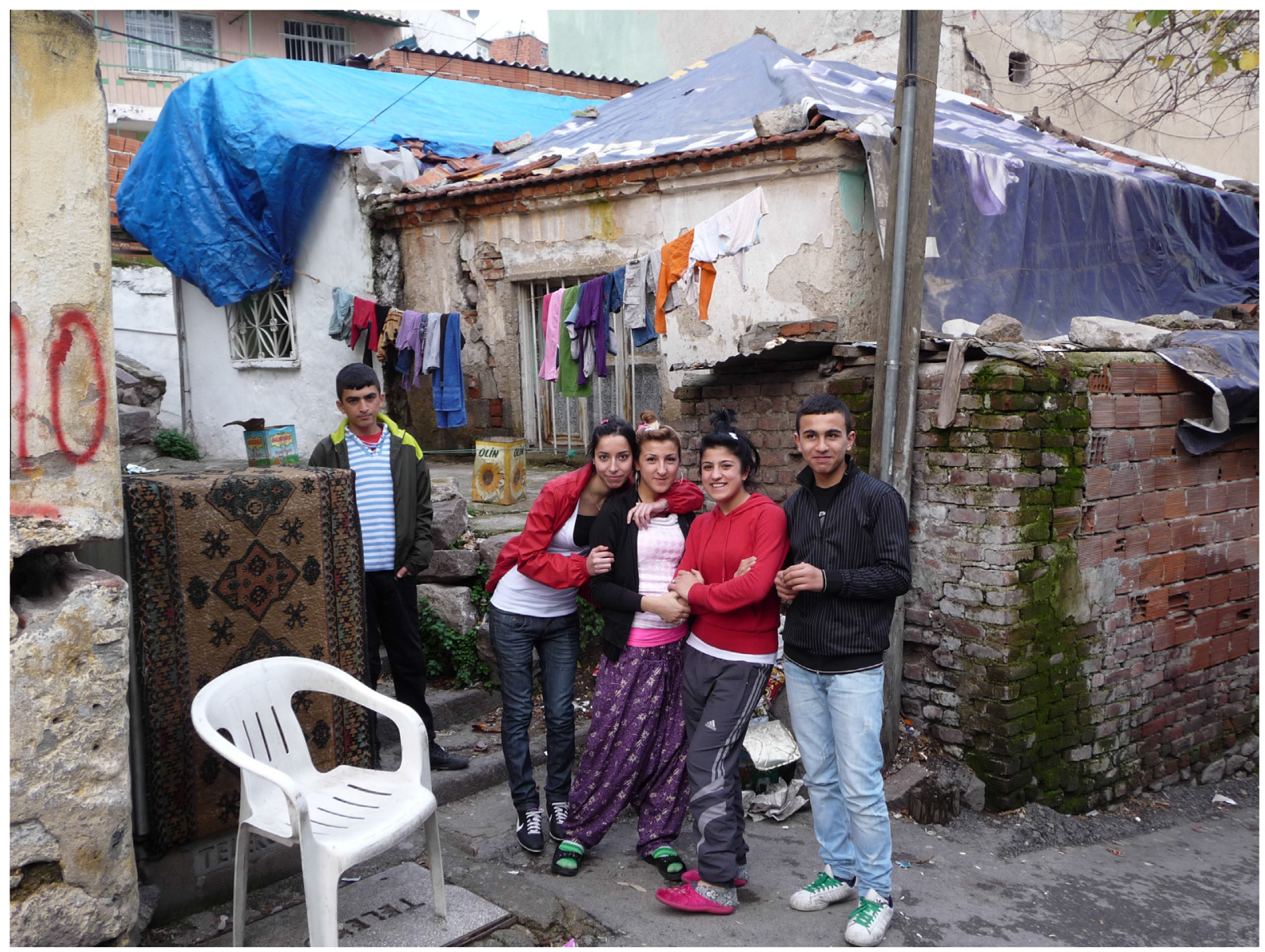

Fig. 13. Group of Kadifekale teenagers socializing in the streets of Kadifekale, 2010 (Author 1 archive).
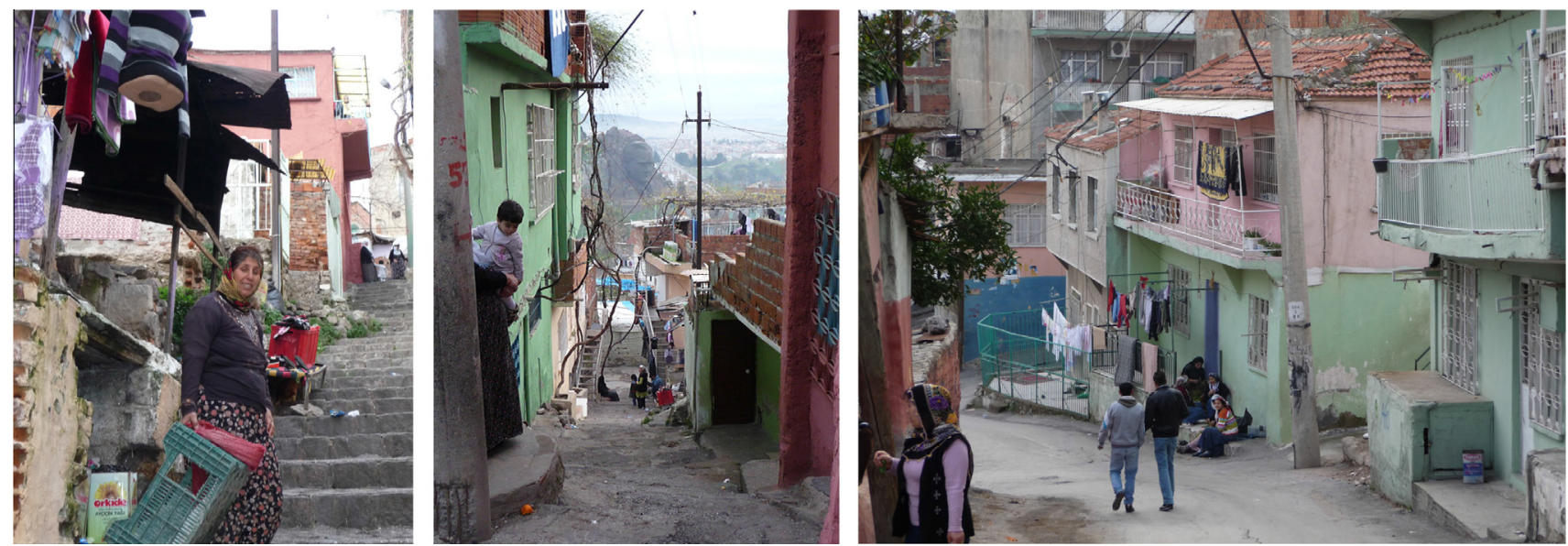

Fig. 14. Women shopping or spending time in the streets of Kadifekale, 2010 (Author 1 archive).

a different, incompatible physical context by tactical alternative re-uses of space.

Shops are also very important spots of public space, as Gehl (1987) suggests, being the main centers of social attraction. Accordingly, the small gecekondu shops in Kadifekale seemed to be very attractive to the inhabitants and highly visible since the ground floors of many houses are used as shops. Having many small shops creates an important opportunity for local women to earn money and improve themselves socially without leaving their neighborhood, or even their houses (Fig. 20). Furthermore, people not only shop there but sit and chat with each other in front or inside the shops, making them spaces of socialization as well as consumption. In the TOKI Uzundere housing project, however, the planners constructed a large modern shopping mall instead of foreseeing the need for an intimate shopping space. The new mall neither provides opportunities for the residents to shop 

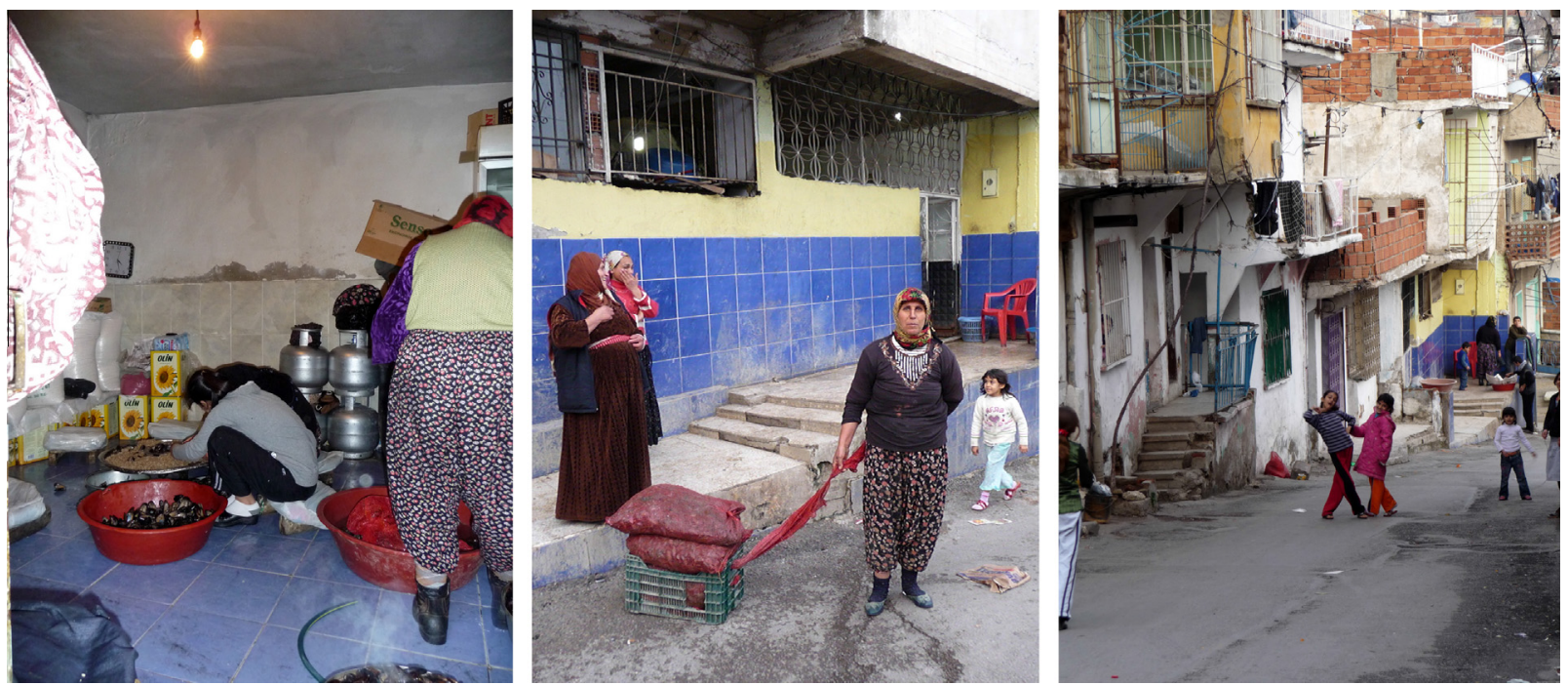

Fig. 15. Women helping each other produce stuffed mussels in Kadifekale, 2010 (Author 1 archive).
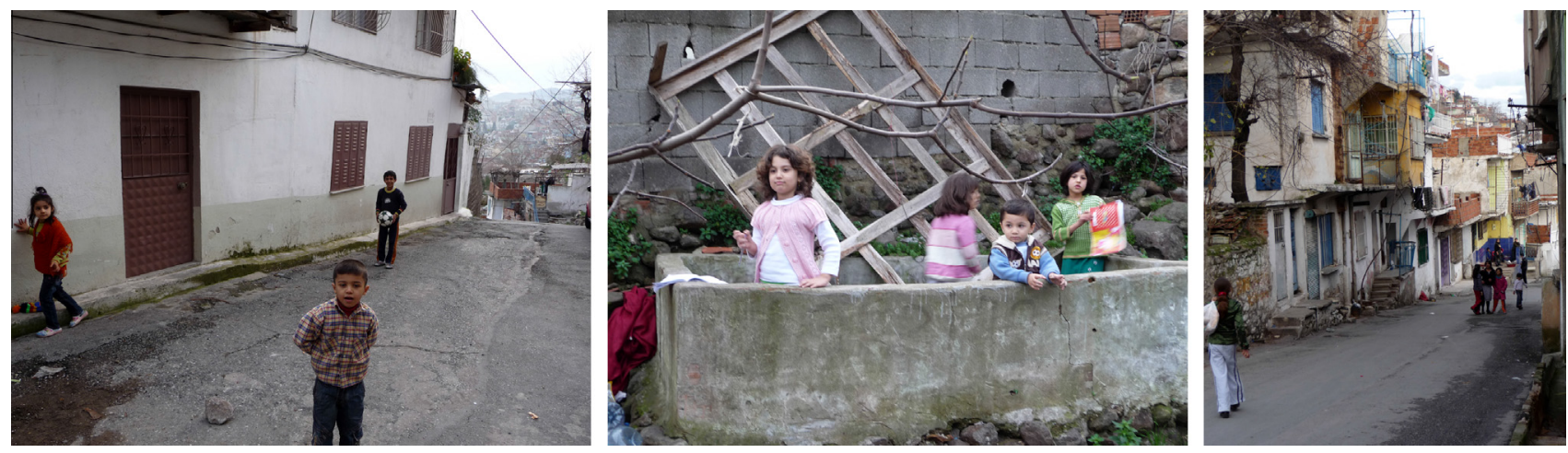

Fig. 16. Children playing in the streets and gardens of their houses in Kadifekale, 2010 (Author 1 archive).
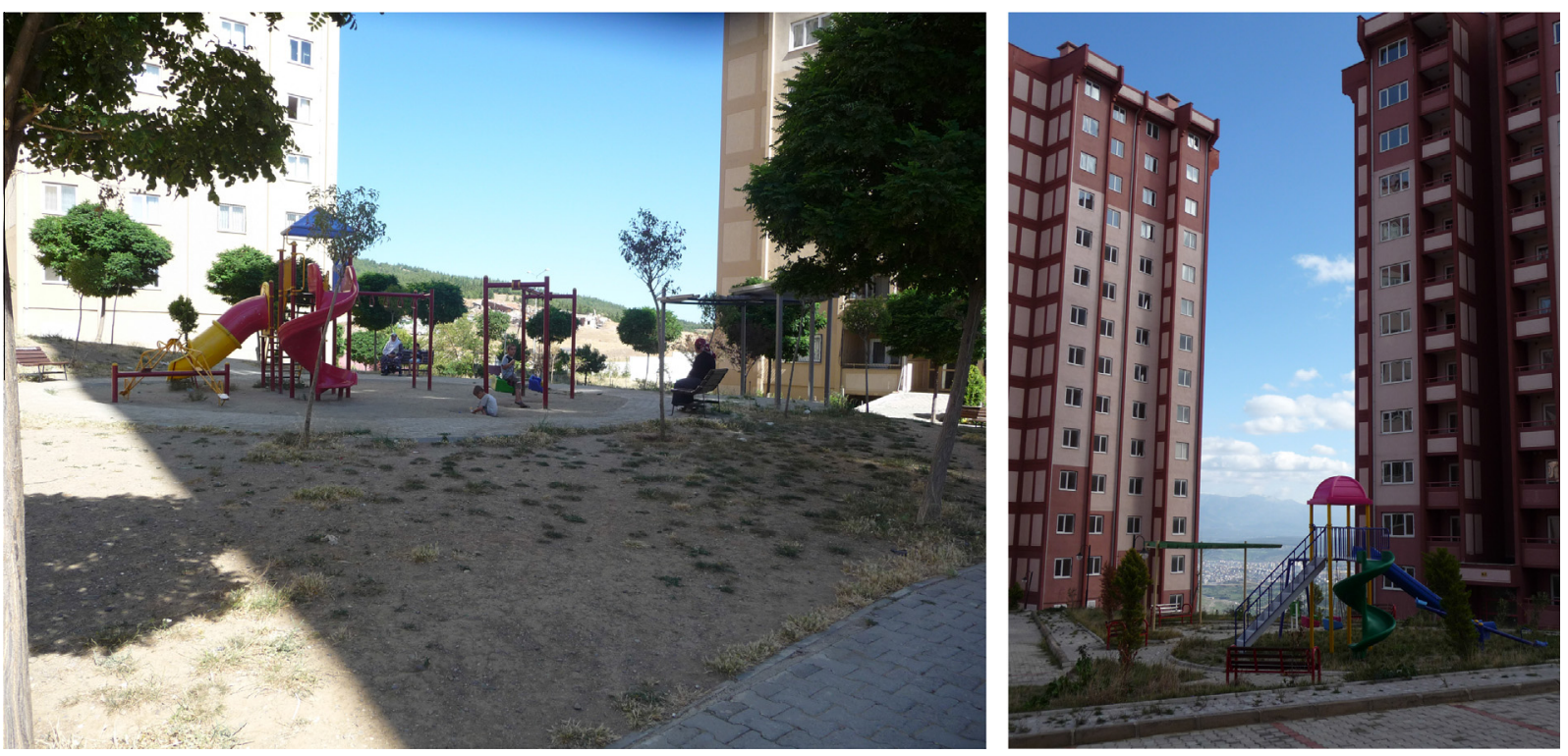

Fig. 17. Children's playgrounds in TOKI Uzundere project site, 2010 and 2013 (Author 1 and 2 archives). 


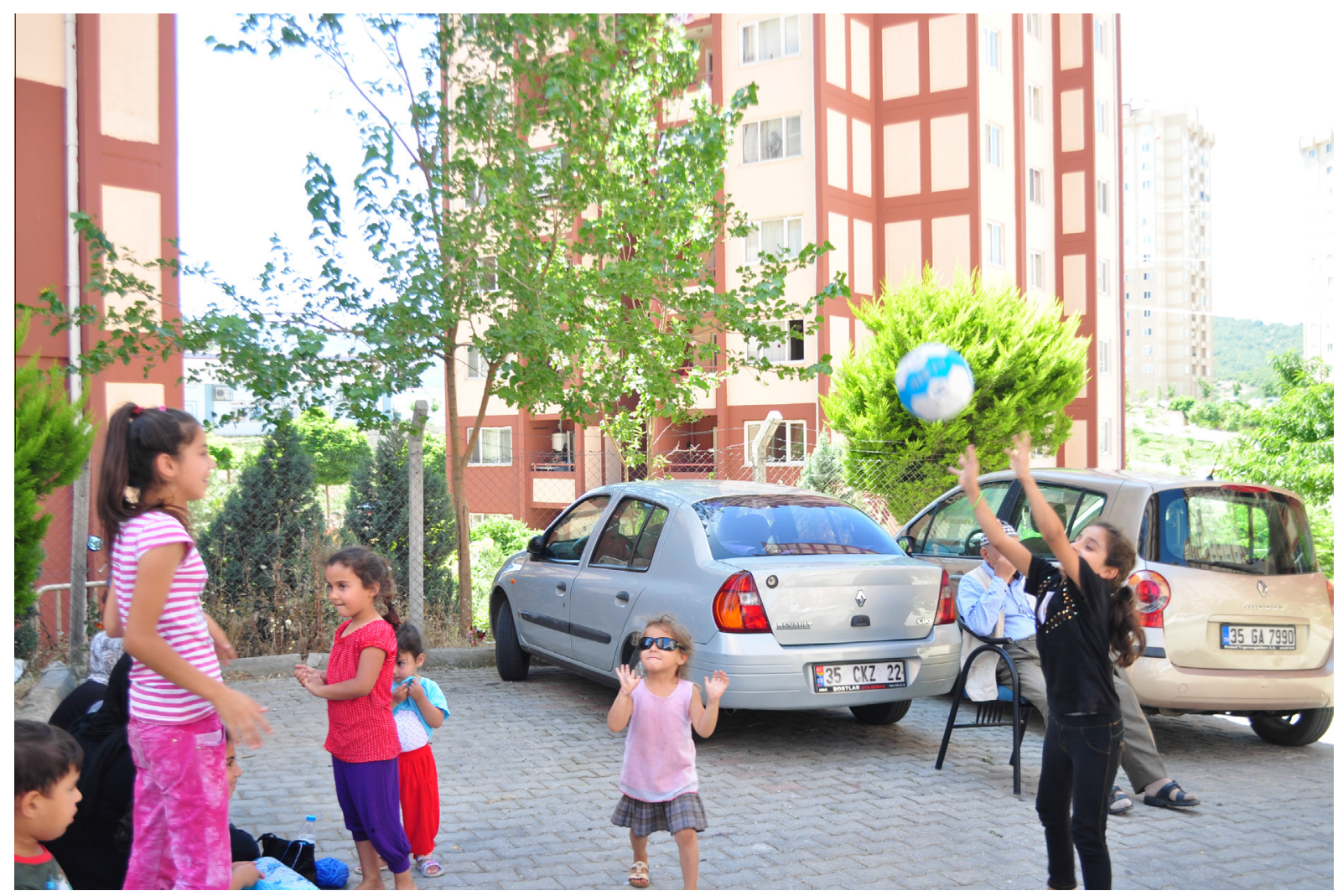

Fig. 18. Children playing among the apartment blocks in TOKI Uzundere, 2014 (Author 1 archive).
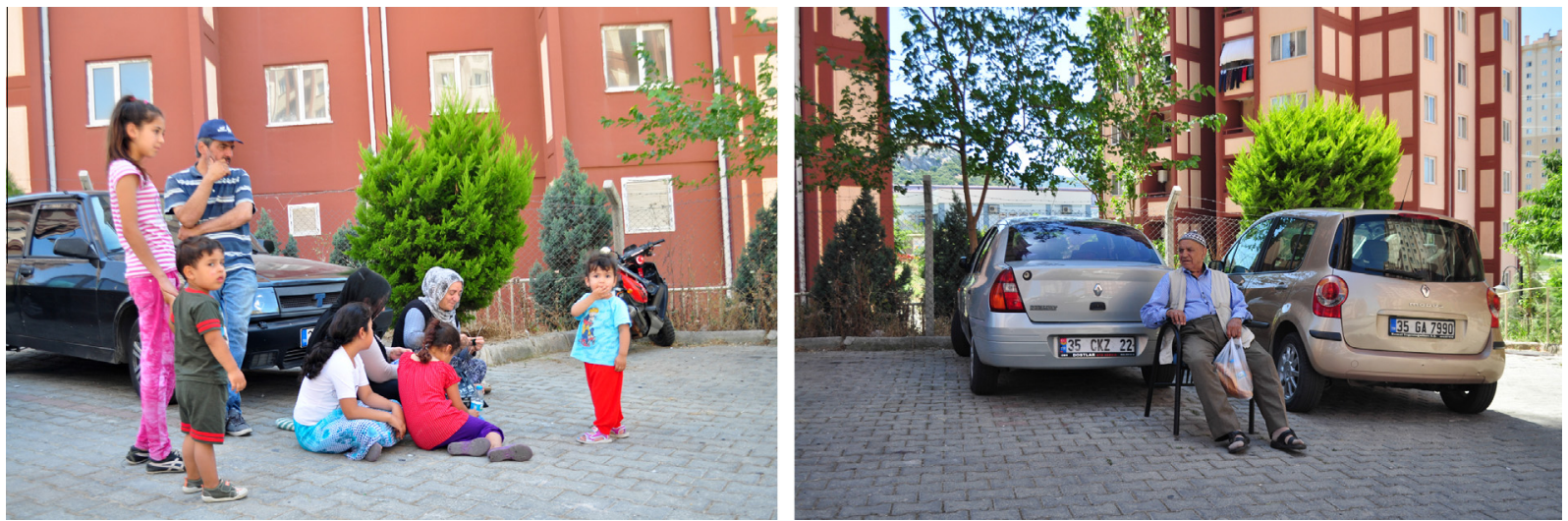

Fig. 19. Use of common areas by women and elderly people in TOKi Uzundere, 2014 (Author 1 archive).

inexpensively nor offers a space for sociability as was the case in Kadifekale (Fig. 21). One of the young male respondents also remarked that they could buy things at the grocery store in Kadifekale on credit, which would never be possible in the Uzundere shopping mall. Although it has been two years since the shopping mall opened in Uzundere, it has not been used to its full extent, with a considerable number of stores still unoccupied. Another indication of the incompatibility between the previous daily practices of the residents and the new space provided by TOKI is that mobile sellers meet the residents' actual needs by visiting every Monday to set up a small bazaar, albeit without the required formal approval from governmental agencies (Fig. 22).

Aware of their fellow residents' need for small shops selling basic essential products at inexpensive prices, some inhabitants in TOKI Uzundere have established portable 'car-shops' - in some cases based on informal credit. It is interesting to note that these car-shops have also become sites of social attraction, as used to be the case in Kadifekale, with women and men sitting on portable chairs around the "mobile shops" to chat with each other. These are very good examples of what De Certeau calls "tactics of the weak". He argues that, while "strategies pin their hopes on the resistance that the establishment of a place offers to the erosion of time; tactics on a clever utilization of time" (De Certeau, 1984, pp. 38-39). All these practices that the previous residents of Kadifekale improvise in TOKI Uzundere reflect alternative and temporary re-uses of the space that was imposed on them by the implementers of the urban transformation project.

Although men do not use public space in TOKI Uzundere as much as women do, the discontinuity between their previous spatial practices and those in TOKI can also be easily observed. Men 

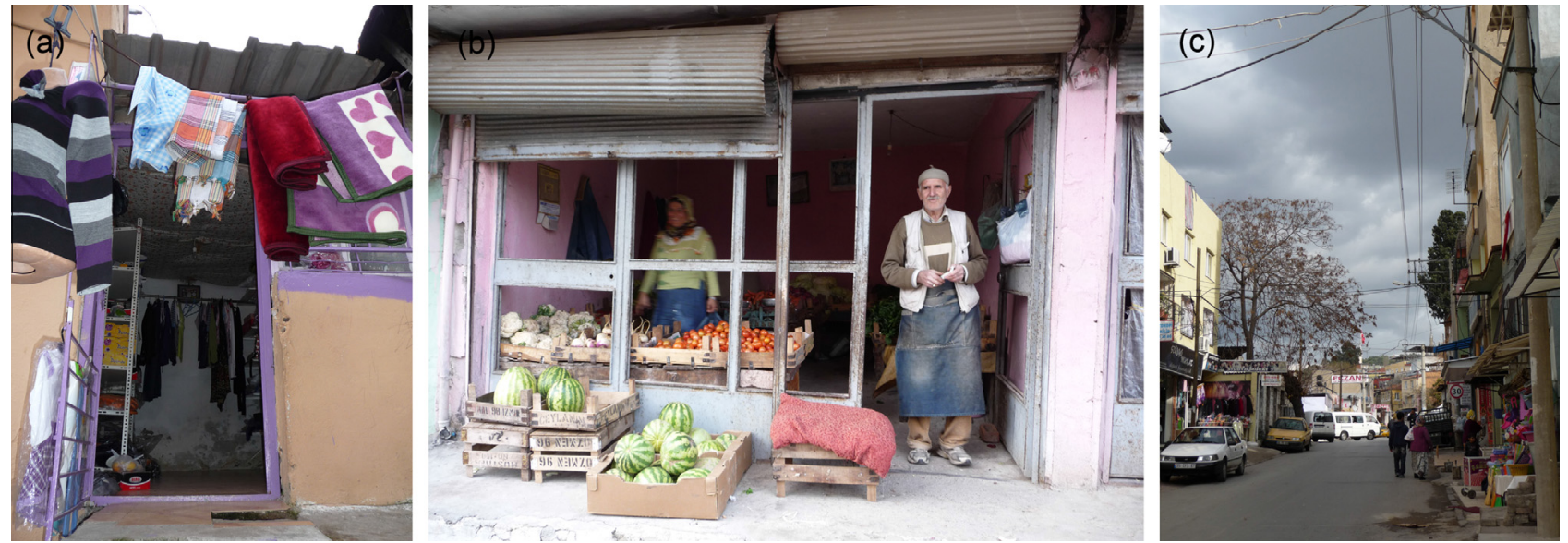

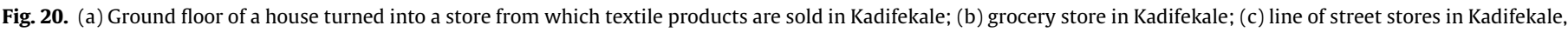
2010 (Author 1 archive).
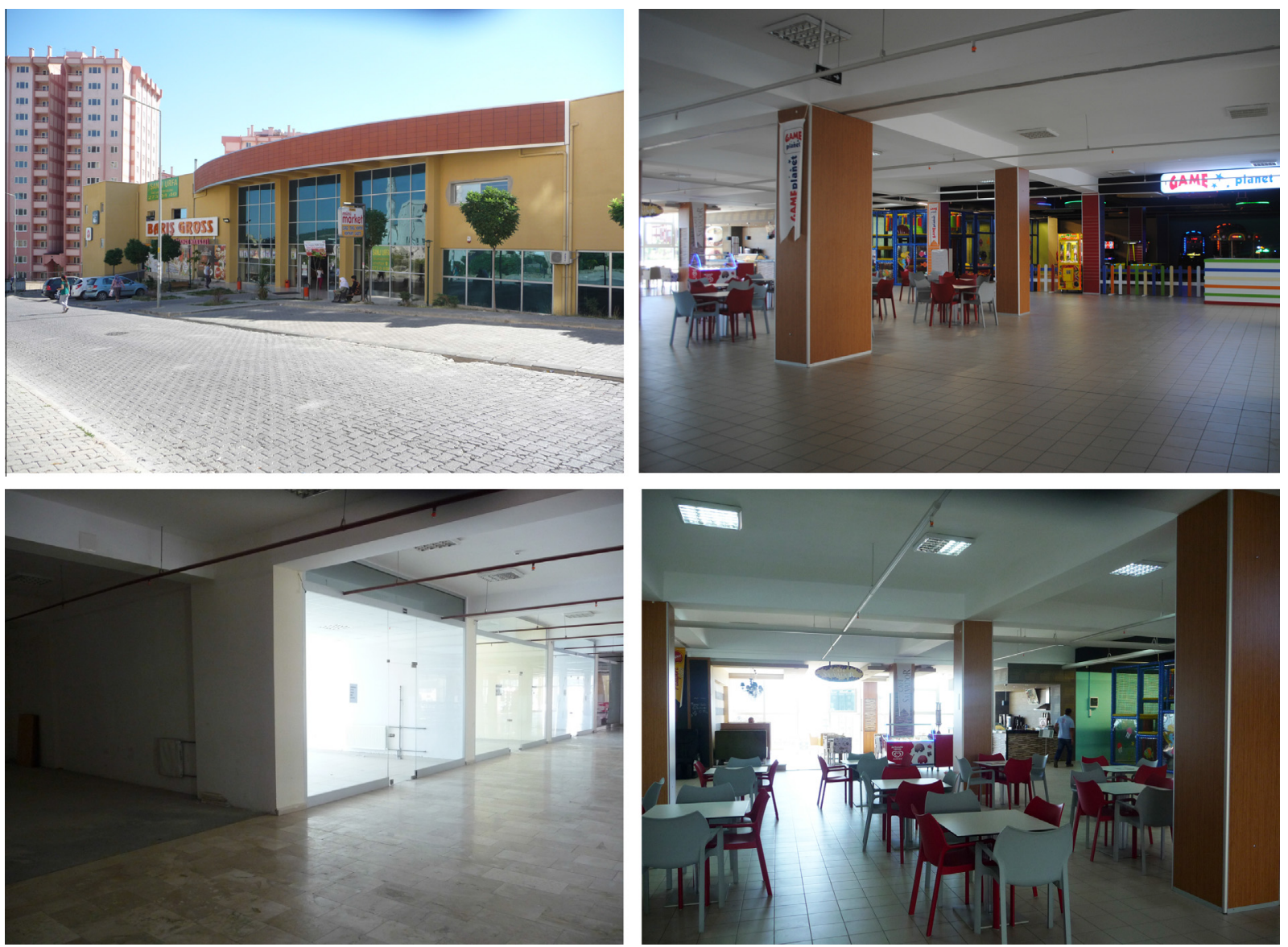

Fig. 21. Shopping mall in TOKI Uzundere, 2010 and 2014 (Author 1 and 2 archives).

generally report that they prefer going to coffee houses in order to meet their friends, either on Sundays or in the evenings, because most of them work for six days a week (Fig. 23). Although there is a coffee house in the shopping mall in Uzundere, this space is not unifying enough to create a social area for the inhabitants (Fig. 24). The interviews confirmed that the coffee house is not regularly visited by relocated male inhabitants since they cannot afford to pay more than they did in Kadifekale. One 58-year-old male respondent complained about the prices of the coffee house:

Yes, there is a coffee house in the mall. The owner of the coffee house does not earn much since the rent of the coffee house costs
3500-4000 Turkish Liras. Besides, the majority of the residents are retired like me. We cannot afford the expenses there. I cannot go there and pay five Liras per day. I have other extra expenses to cover in TOKI, such as the heating, electricity, water bills and residential dues.

Another reason for the infrequent use of the coffee house in TOKI Uzundere is that it is located in a shopping mall rather than as a separate building, as it was in Kadifekale. Not being originally designed as a coffee house but as one of the stores in the shopping mall, also significantly affects the spirit of the place, in contrast to 

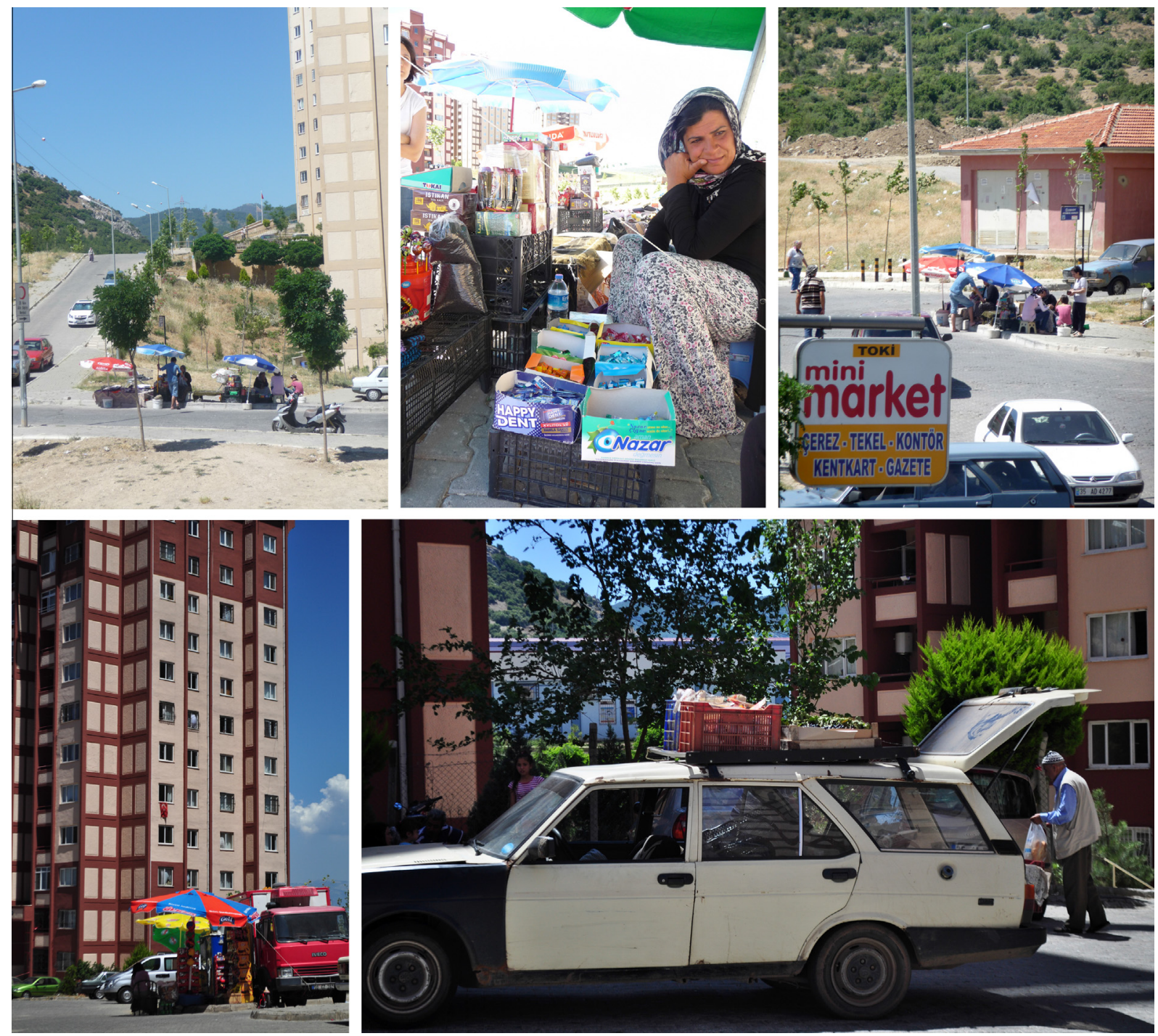

Fig. 22. Alternative shopping points in TOKI Uzundere, 2013 and 2014 (Author 1 archive).

the individuality of the coffee house in Kadifekale, which provided its users with open terraces to support the neighborhood culture. In contrast, it is interesting to note that some inhabitants of TOKI Uzundere have established spontaneous meeting places next to minibus stops, which now serve as alternative pavement coffee houses (Fig. 25), as constituting another example of a tactical intervention in space.

\section{The production of meaning through the social aspects of each neighborhood}

Relph (2008, p. 36) argues that [t]he relationship between community and place is a very powerful one in which each reinforces the identity of the other, and in which the landscape is very much an expression of communally-held beliefs and values and interpersonal involvements. The identity of place is also supported by sensual recognition of the environment, which is established through the socio-cultural characteristics of the inhabitants.More specifically, aAccording to Tuan (1977), visual recognition, one of the simplest signs of intimacy in the neighborhood, is primarily exemplified by the street because it becomes an intimate experience and sentiment for the resident who passes along it every day. Learning a new neighborhood requires the identification of significant localities, such as street corners or architectural landmarks. ${ }^{14}$ The importance of these visible signs comes from the fact that they serve to enhance people's sense of identity and bring awareness and loyalty to the place. Through memories of sounds and smells, of both communal activities and homely pleasures, the intense relationship with one's 'homeland' develops.

Kadifekale inhabitants, as members of a largely forced migrant population from Mardin, ${ }^{15}$ have struggled to keep their traditional values alive in order to sustain their own cultural characteristics in the neighborhood. According to the interview respondents, Kadifekale reminds them of their homeland back in the East in that they have recreated social relations in a quite similar way in Izmir to

\footnotetext{
14 Lynch (1960) reported that users understand their surroundings in consistent and predictable ways, forming mental maps with five elements. These are paths (the streets, sidewalks, trails and other channels in which people travel), edges (perceived boundaries, such as walls, buildings and shorelines), districts (relatively large sections of the city distinguished by some identity or character), nodes (focal points, intersections or loci) and landmarks (readily-identifiable objects which serve as external reference points).

15 The population of the Kadifekale district was reported as mainly comprising migrants from the East and South-East of Turkey (Karayiğit, 2005).
} 


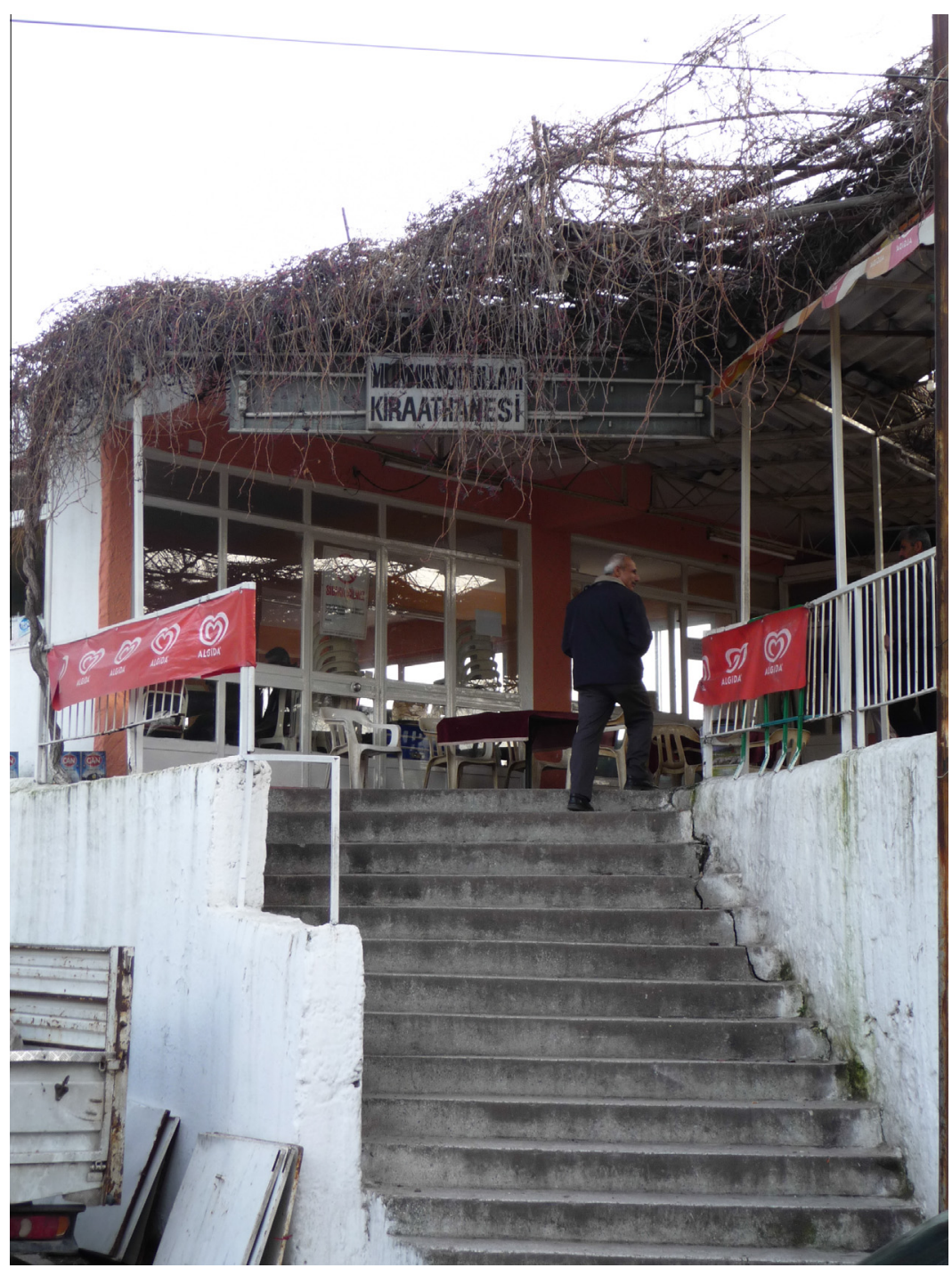

Fig. 23. Coffee house used by the male inhabitants in Kadifekale for socializing, 2010 (Author 1 archive).
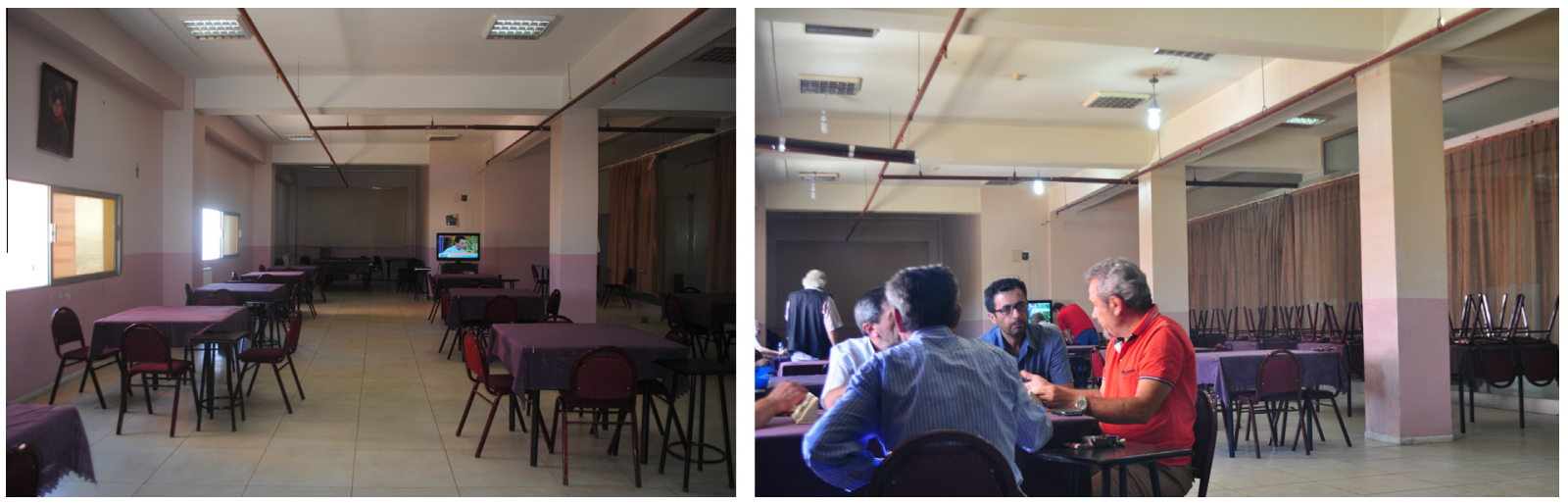

Fig. 24. Coffee house in TOKI Uzundere shopping mall, 2013 (Author 1 archive).

those they experienced back in their hometowns. As one of the respondents, who was 20 years old, put it:

We had several reasons to settle in this neighborhood, such as having relatives residing here and also job opportunities nearby. Additionally, this neighborhood reminds us of our own hometown. We call it 'small Mardin'.
Another 36-year-old female respondent stated that all her fellow villagers migrated to Kadifekale when their village was evacuated by the state:

When our village was destroyed, there was no one left there. Everyone came here. We came here and owned a house here, but they [referring to state officials] do not let us reside here also. 


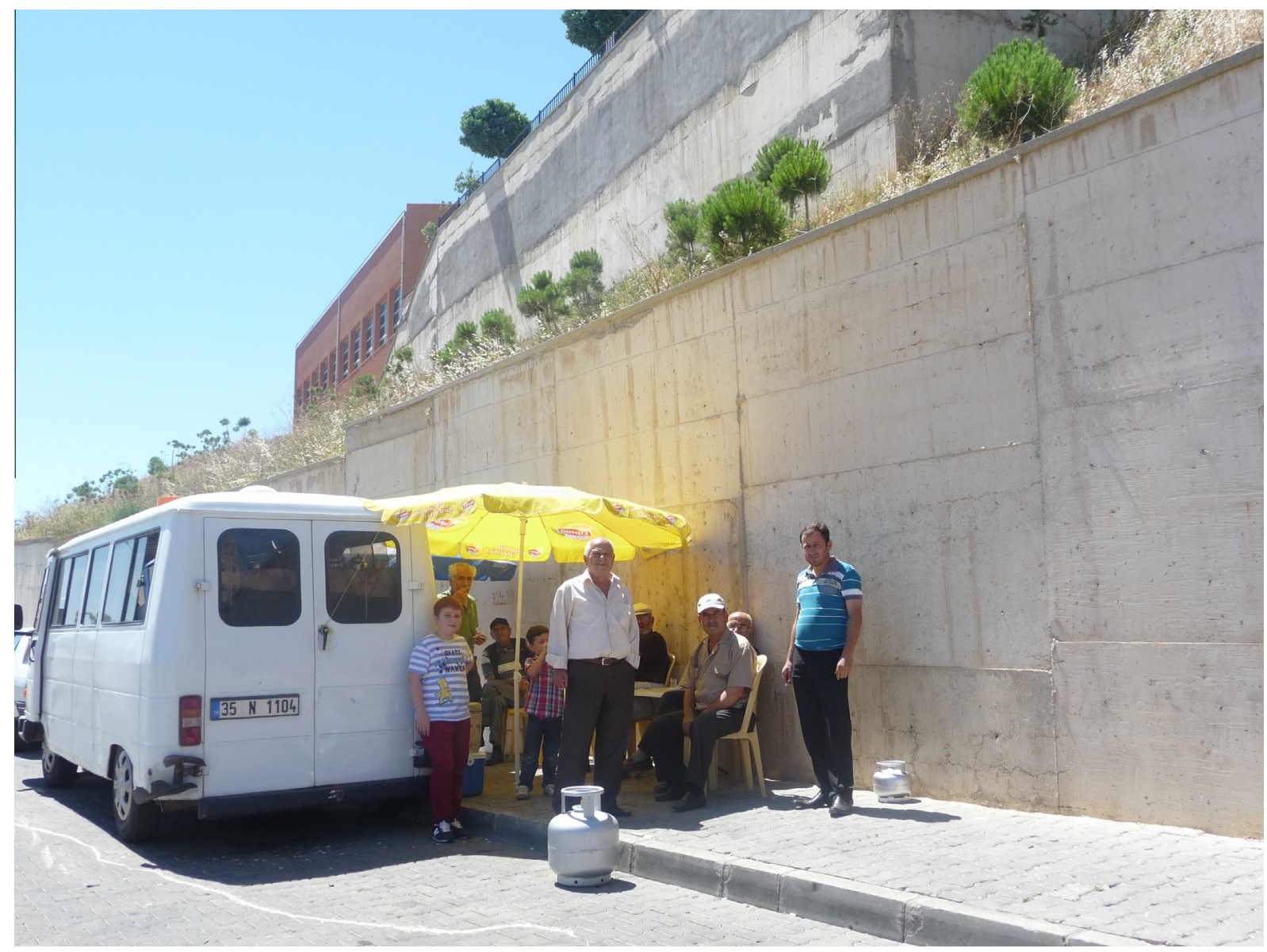

Fig. 25. Alternative pavement coffee house at a minibus stop in TOKi Uzundere (Author 1 archive).

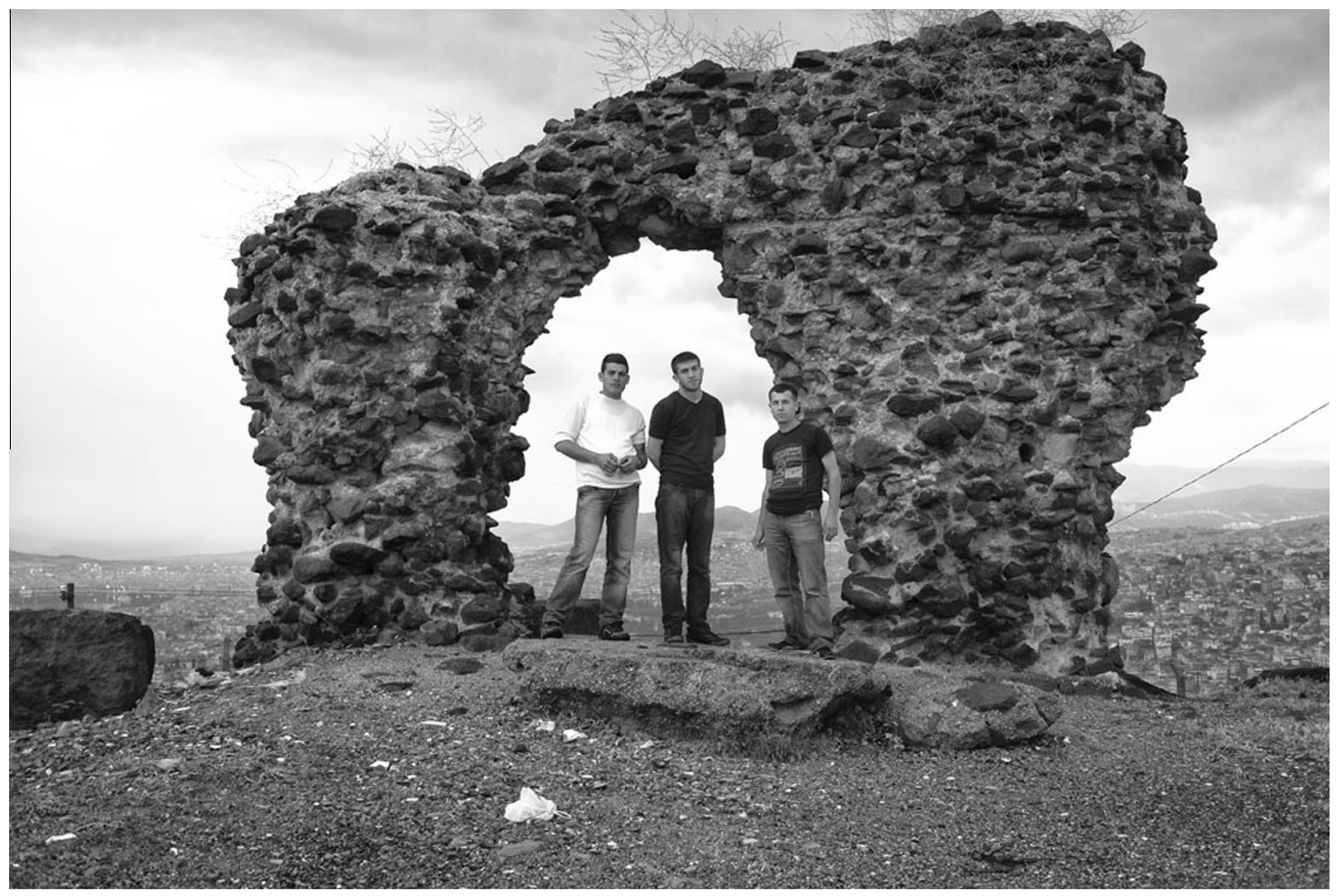

Fig. 26. View of part of the historic walls of Kadifekale castle used as a socializing place (Donuktan archive, 2010) <http://www.kodacollective.com/photographers>. 
First they kicked us out from Mardin and now from here. So this is the second time we experience exile. I wish, at least, they could have created a more suitable place for us to live in [referring to the Uzundere apartments].

Social solidarity, though decreasing in intensity, particularly due to emerging class differences in Kadifekale, still plays an important role in the daily survival of poor families. Linguistic and cultural commonalities give migrants a feeling of still being in a cultural community that reminds them of their former village communities in Mardin. Spatially, their homes in Kadifekale, the streets and the smells all seem reminiscent of their homeland. In contrast, TOKI Uzundere lacks many of those qualities that give meaning to a neighborhood, mainly because it has no similarities with what the inhabitants were used to seeing, hearing and smelling, whether in their homelands or Kadifekale.

Most of the respondents referred to the strong emotional bond that they have for Kadifekale, having lived there for more than 15 years. Kadifekale's streets and its historic castle gave the inhabitants a means of visual recognition, from which they developed their feelings of intimacy toward it. Informal conversations, particularly with young people, who prefer meeting in front of the old walls of the castle, revealed its meaning as a socializing place for many inhabitants of the neighborhood (Fig. 26). As one of the young male respondents stated:

Our neighbors here are mostly from Mardin. We greet each other every morning. Besides, I meet my cousins every day. Also, I meet my friends at the gate of the castle or around the walls of the castle, at the coffee house or here [at home]. Before, we used to sit down and spend time on the sidewalks of the street, but we go to the internet café nowadays.
The coffee house and the office of the headman can also be seen as places of visual recognition. They are unique places in the neighborhood, located right at the entrance to Kadifekale's market place, with the men using the coffee house for socializing purposes, and both men and women making daily visits to the office of the local headman. Thus, in dealing with daily bureaucratic tasks, they interact with each other. The office of the local headman was also the main place for people to communicate news during the implementation of the transformation project, so that it served as one of the main places for critical discussion and public opinion formation.

In addition to the importance of sight in the recognition of a neighborhood as a socially intimate space, another sense, smell, should also be considered further as an important factor in contributing to the intimacy of place for its inhabitants. Rodaway (quoted in Bondie \& Christie, 2002, p. 293) mentions that the association of odors with particular things, organisms, situations and emotions all contribute to a sense of place. Lefebvre (1998) also draws attention to the sense of smell when he says that "where an intimacy occurs between 'subject' and 'object', it must surely be the world of smell and the places where they reside" (quoted in Bondie \& Christie, 2002, p. 293). Odors may lend a character to objects and places, while making them distinctive and easy to identify and remember. "Odor is also capable of suggesting mass and volume in the way that some odors, like tuberose or musk, arouse feelings of heaviness; others may suggest delicacy, thinness or lightness" (Tuan, 1977).

In the case of Kadifekale, in terms of olfactory recognition, the public smell of baking on the street and the cooking aromas from houses create a sense of familiarity with the neighborhood and village life back in Mardin. People are used to baking their own bread in the communally-used public ovens so a certain aroma of baking

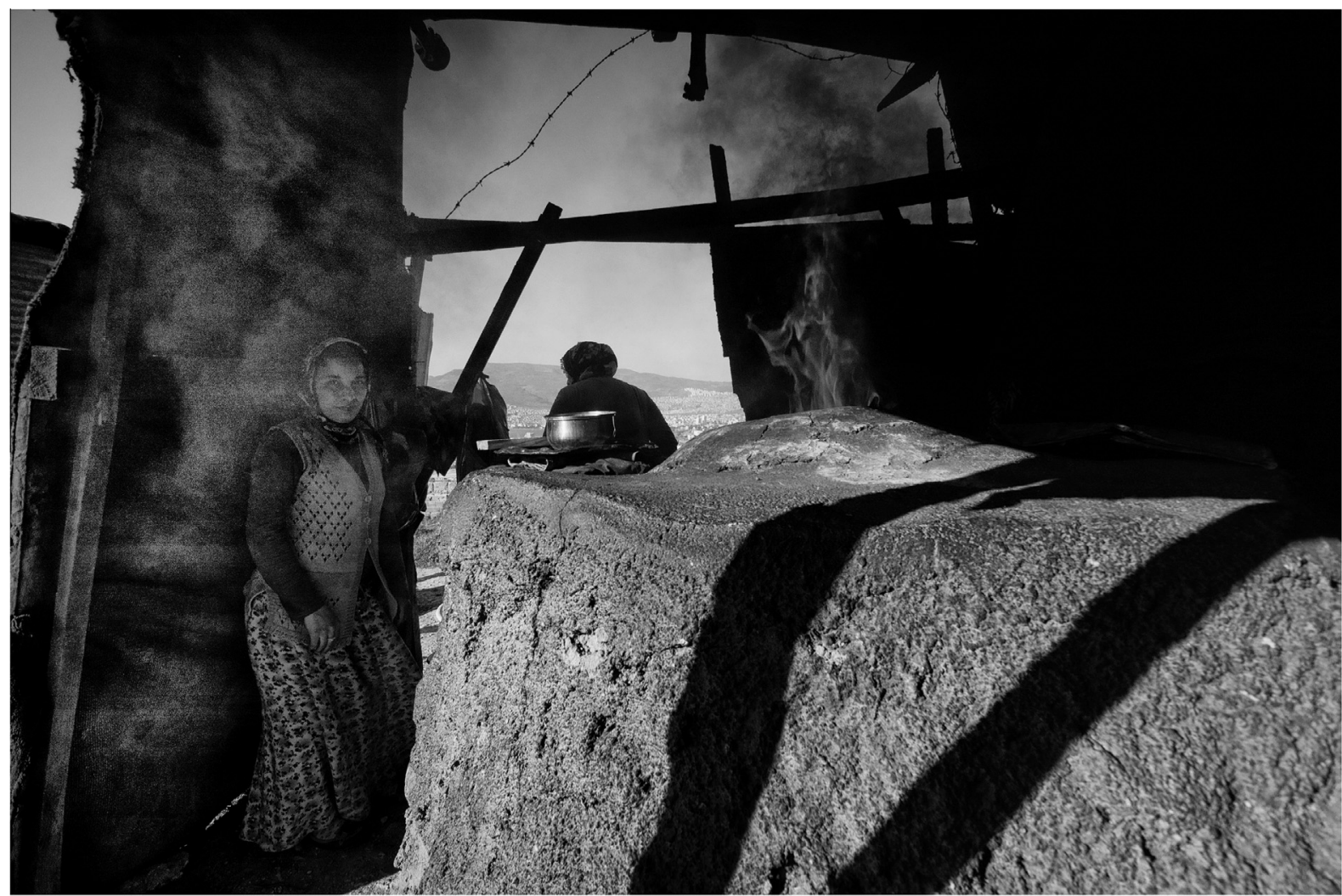

Fig. 27. Public oven in Kadifekale (Serkan Çolak/MahzenPhotos archive). 


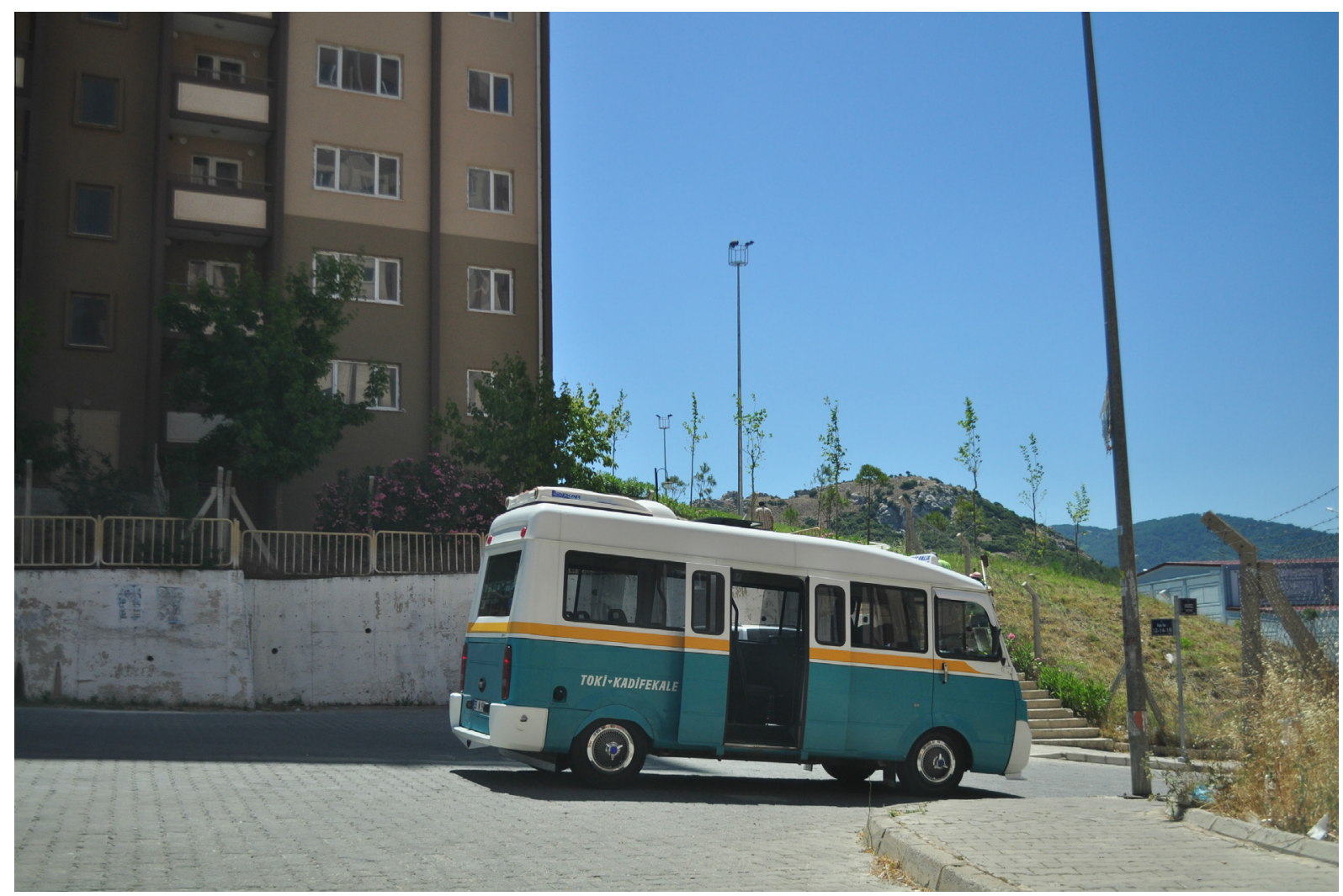

Fig. 28. TOKI-Kadifekale minibus (Author 1 archive).

permeates all the neighborhood streets (Fig. 27). However, a public oven is not permitted in the "sterile" living conditions of TOKI Uzundere. As another example of close community relations between neighbors, female interviewees reported how they know what their neighbor is cooking from the smell coming from their kitchens, remarking that, in Kadifekale, they often share what they cook with close-by neighbors.

Interviewees often mentioned the importance and the meaning of having close relationships with their neighbors, which creates deep connections between the people and their houses, replicating the tight community relations back in Mardin. All the participants agreed that they have strong relationships with their neighbors, and women especially prefer spending most of their time at each other's houses to help in doing the housework, caring for their children or just conversing. Respondents often stated that they leave the keys of their houses with neighbors when they are away so that the neighbors can take care of their houses and warn them of any emergencies. Indeed, in Kadifekale, they have such deep trust in their neighbors that they never even need to lock their front doors:

We are not only neighbors, but also like sisters and brothers, even like mothers and fathers for each other. That is why we love our neighborhood. We help each other. When we leave the neighborhood, we give our key to one of our neighbors. Our doors are open and we feel secure in this neighborhood. We have such great bonds among our neighbors that we feel as if we live in the same house together.

It is interesting to note that each of the following 39, 19 and 35 -year-old female respondents say very similar things regarding the strong community structure and feeling of security in Kadifekale:

Having a detached house is the best part of living here. You come in and go out easily without any effort since it is one story. Even our door is open the whole day; no one enters without permission. If we need to go somewhere else, we leave our key with a neighbor and if someone needs to visit her/his hometown, we feel responsible to keep her/his house safe. Our children play anywhere around the house, in the garden or even on the streets.

Everyone knows each other. We do not have any trouble about security. Although we feel that we need to lock our door at nights, we are not bothered to lock it during the day.

What we love about our house the most is its location in the city and its proximity to the city center as well as to our relatives.

In that respect, for most of the migrants, to move to TOKI Uzundere means being detached from their social roots and these feelings of trust and security. Despite the fact that some of them moved to TOKI houses with their relatives or neighbors, the modernist planning of the new housing area has not let the communal interaction patterns continue as they did in Kadifekale, particularly regarding relationships between women. As Erman (1997, p. 91, quoted in Akbulut \& Başlık, 2011, p. 4) asserts, "[t]his is so because of the way of life gecekondu housing provides, for example, close relationship with neighbors and spontaneous relationships with the outside". In order to sustain existing networks and establish relationships with their new neighbors, some relocated Kadifekale women set a date in each week to gather in one of the apartments to socialize. Interestingly, a new minibus route was established between Kadifekale and TOKI Uzundere in a reflection of the residents' intense need to maintain their old networks in Kadifekale culture (Fig. 28).

\section{Evaluation and conclusion}

The socio-spatial analysis reported here reveals that there is a striking dissonance between physical space and the social life experiences of TOKI Uzundere inhabitants who previously lived 
in Kadifekale. Although the urban transformation project and the relocation process have been idealized and presented as a perfect solution by governmental agencies, it both have failed to respond to the socio-spatial needs of Kadifekale inhabitants. It can therefore be asserted that the inhabitants of Kadifekale are likely to face many more problems in the future beyond the severe problems they have already faced concerning their daily practices and social relations in TOKI Uzundere.

Kadifekale is a space where social interactions within the neighborhood make it a 'place' for its inhabitants whereas TOKI Uzundere remains primarily a space of its producers rather than the users, as seen in the cases of the neglected playgrounds, shopping mall and coffee house. It is impossible to claim that the designed space of the project implementers satisfies the needs of its inhabitants regarding their social life and daily practices. Rather, the users of the space have been blatantly disregarded, meaning that "representations of space" and "spatial practice", in a Lefebvrian sense, are in serious contradiction. In particular, the TOKI housing project's lack of appropriate communal places and intimate spaces around the housing units particularly excludes women from social life, who are likely to miss this intimacy in TOKI Uzundere, having been used to living at street level in Kadifekale.

It is certain that deficiencies in the planning of TOKI Uzundere have already had several negative consequences for the residents' daily life that may have further implications for their social life. The relocated community has been separated from their neighborhood physically then fragmented socially because the project implementers failed to consider the residents' accustomed home-neighborhood environment and communication zones. Such a development seems to carry the subliminal message that these divided communities are being isolated from the rest of society and kept outside the 'border'.

This study combined the concepts of urban transformation regarding the relationship between spatial and social issues while examining the consequences of relocation from Kadifekale to TOKI Uzundere in terms of changing spatial conditions at a neighborhood scale. It hopefully highlights the need for locally informed urban transformation and planning projects. Future research in the area would be valuable in providing a more substantial analysis of the longer-term impacts of this relocation. Furthermore, the effects observed in this case could be multiplied through other TOKİ cases.

\section{References}

Akbulut, M. R., \& Başlık, S. (2011). Transformation of perception of the Gecekondu phenomenon. METU Journal of the Faculty of Architecture, 28(2), 1-44.

Altınörs Çırak, A., \& Yörür, N. (2006). İzmir Onur Mahallesi örneğinde farkl söylemler ve taraflar açısından kentsel dönüşümün iki yüzü. Planlama, 37 $79-88$
Ataöv, A., \& Osmay, S. (2007). Türkiye'de kentsel dönüșüme yöntemsel bir yaklaşım. METU Journal of the Faculty of Architecture, 24(2), 57-82.

Aydınlı, H. İ., \& Turan, H. (2012). Kuramsal ve yasal çerçevede Türkiye'de kentsel dönüşüm. Selçuk Üniversitesi Sosyal Bilimler Enstitüsü Dergisi, 28, 61-70.

Balamir, M. (2006). Kentsel dönüšüm, Round-table discussion. Dosya, 01, Bülten 40 (pp. 16-39).

Baran, H., \& Çiçek, Ü. (2006). Kadifekale'de durum değerlendirmesi. İzmir: Izmir Chamber of Commerce.

Barlas, M. A. (2006). Urban streets $\mathcal{E}$ urban rituals. Ankara: METU Faculty of Architecture Printing Workshop.

Berman, M. (2007). The family of the eyes and the fire of the Macadam. In M. Larice \& E. Macdonald (Eds.), The urban design reader (pp. 5-12). New York: Routledge.

Bondi, L., \& Christie, H. (2002). Working out the urban: Gender relations and the city. In G. Bridge \& S. Watson (Eds.), A companion to the city (pp. 292-306). New York: Wiley-Blackwell.

Bourdieu, P. (1979). Algeria 1960. London and New York: Cambridge University Press.

Brenner, N. (1997). Global, fragmented, hierarchical: Henri Lefebvre's geographies of globalization. Public Culture, 10(1), 135-167.

Building Turkey of the Future (2011). [online] Available at: <http://www.toki.gov. tr/AppResources/UserFiles/files/TOKI-11_ENG.pdf> Accessed 15.03.15.

De Certeau, M. (1984). The practice of everyday life. California: University of California Press.

Demirtaş, N. (2009). Social spatialization in a Turkish squatter settlement: The dualism of strategy and tactic reconsidered. European University Studies Series XXII, Sociology. Frankfurt am Main: Peter Lang Publishing House.

Demirtas, N., \& Sen, S. (2007). Varos identity: The redefinition of low-income settlements in Turkey. Middle Eastern Studies, 43, 1.

Demirtaş-Milz, N. (2013). Regime of informality in neoliberal times in Turkey: The case of the Kadifekale urban transformation project. International Journal of Urban and Regional Research, (SSCI), 37(2), 689-714.

Gehl, J. (1987). Life between buildings. New York: Van Nostrand Reinhold International Company Limited.

Ghannam, F. (2002). Remaking the modern: Space, relocation and the politics of identity in a global Cairo. Cairo: University of California Press.

Housing Development Administration of Turkey, 2005. EIA Report of Izmir Uzundere Public Housing Project. Ankara.

Karayiğit, A. (2005). Kadifekale'nin sosyo-ekonomik profili ve sorunları. İzmir: İzmir Chamber of Commerce.

[Onlne] Available at: <http://www.kodacollective.com/photographers> Accessed 05.12.14.

Kuyucu, T., \& Unsal, O. (2010). Urban transformation and the state-led property transfer: an analysis of two cases of urban renewal in İstanbul. Urban Studies, 47(7), 1479-1499.

Lefebvre, H. (1998). The production of space. Oxford: Blackwell.

Lynch, K. (1960). The image of the city. Cambridge and Massachusetts: The MIT Press. Relph, E. (2008). Place and placelessness. London: Pion Press.

Saraçoğlu, C., \& Demirtaş-Milz (2014). 'Natural disasters' as a strategy of governing urban transformation: A case study from Izmir/Kadifekale. Disasters (SSCI), 38(1), 178-201.

Shields, R. (1991). Places on the margin. London and New York: Routledge.

Tekeli, İ. (2014). Sunuş. In A. Türkün (Ed.), Mülk, mahal, insan: İstanbul'da kentsel dönüşüm (pp. xxi-xxiv). İstanbul: İstanbul Bilgi Üniversitesi Yayınları.

Trancik, R. (1986). Finding lost space. Theories of urban design. New York: John Wiley and Sons Inc.

Tuan, Y. F. (1977). Space and place. Minneapolis: University of Minnesota Press.

Türkün, A., Öktem Ünsal, B., \& Yapıcı, M. (2014). 1980 sonrasında İstanbul'da kentsel dönüşüm: Mevzuat, söylem, aktörler ve dönüșümün hedefindeki alanlar. In: A. Türkün (Ed.), Mülk, mahal, insan: İstanbul'da kentsel dönüşüm (pp. 79-140). İstanbul: İstanbul Bilgi Üniversitesi Yayınları.

Ulusoy, H. A. (2006). Kentsel dönüşüm ve/veya kent toprakları üzerinden sağlanan rant'in bölüşümü. Dosya 01, Bülten 40 (pp. 4-6).

Ünsal, Ö., \& Kuyucu, T. (2010). Challenging the neo-liberal regime: Regeneration and resistance in Başıüyük and Tarlabaşı. In D. Göktürk, L. Soysal, \& I. Türeli (Eds.), Orienting Istanbul: Cultural Capital of Europe? (pp 51-70). London and New York: Routledge. 